\title{
FROM ORDER TO PROSPERITY: THE IMPORTANCE OF COMPETITION IN THE SOCIAL MARKET ECONOMY MODEL
}

\author{
Vladan Ivanovic* \\ Faculty of Economics, University of Kragujevac, Kragujevac, The Republic of Serbia
}

Searching for an institutional structure which enables economic success is in the midst of the practical efforts of governments all around the world, as well as the academic studies endeavoring to understand the sources of success in the most prosperous national economies. The supremacy of the German economy in the European Union, as well as worldwide - from the level of the GDP per capita to high productivity, innovativeness and export performances - is the basic motivation this study rests on. Due to the fact that, unlike a failure, an economic success is always achieved in the long run, this study is aimed at revealing the (historical) institutional roots that have paved the way for the economic success of contemporary Germany. In that context, the model of the Social market economy, i.e. the competitive order (Wettbewerbsordnung), its meaning and importance in solving the allocative equation and reaching the high levels of economic efficiency are the subject matter of analysis in this paper. The key results refer to the identification of the diverse economic and social benefits that a competitive order brings into being, as well as the determination of and pointing to the essential institutional preconditions which such an order is feasible in.

Keywords: Social market economy, German model, competition, economic efficiency, institutions

JEL Classification: B25, B52, P10

\section{INTRODUCTION}

There is abundant evidence in the economic history of the attempts various countries have made in order to reform their economic systems. Successful stories are, however, rare. Although the development of the majority of today's developed countries can be seen as an evolutionary path, rarely or never interrupted

* Correspondence to: V. Ivanovic, Faculty of Economics, University of Kragujevac, Dj. Pucara 3, 34000 Kragujevac, The Republic of Serbia; e-mail: vivanovic@kg.ac.rs by radical social, political, or economic changes, yet there are some exceptions. One of these exceptions is the German model of the Social market economy (SME). The decisive moment in the emergence of this model relates to the monetary reform conducted in West Germany in 1948. The way in which the transformation came into being and the principles by which it was shaped were to a large extent the opposite of the practices in other Western countries at that time. The SME model was based on a free market mechanism and a strong institutional structure 
with limited state intervention. It was quite different from the extensive state regulation of the economy in some other developed countries, especially Great Britain under the rule of the Labor Party after WWII. Furthermore, it was a radical breakthrough not only with respect to the period when National Socialists were in power, but also with respect to the period preceding 1933. Even in the period of the Weimar Republic, the German economy was faced with a serious malfunction and was burdened with numerous social and economic problems. Even the rising of National Socialists to power can to a large extent be explained by the weaknesses of the system that had preceded them.

The ideas which the SME model is based on have had and still have a great influence on the institutional design in many countries and supranational organizations. Institutional solutions, especially those related to the high degree of independence of the German Bundesbank, have had a major impact on the institutional solutions that were applied in transition economies (Loungani \& Sheets, 1997), as well as in developed countries, such as Great Britain (Hielscher \& Markwardt, 2012). Particularly significant has been the impact on the institutional design of the ECB (Berger, 2006). On the other hand, the numerous challenges which developing countries and rapidly growing economies are being faced with, especially given the recent failures (in most of them) and the new risks created by the onset of the financial and economic crisis in 2008, the SME model can represent a significant alternative to further development in these countries (Wrobel, 2012). Some authors (John, 2007; Hillebrand, 2015) point to the potential significance of the SME model for redesigning the institutions which the economic and social policies at the EU level lie on. According to the EU founding agreements, the open market economy and free competition are the core mechanisms of an economic system. They are construction elements in the SME model as well. The potential of the SME model is also reflected in the comprehensiveness that addresses the economic reality (Wrobel, 2014) enabling the creation of the institutional environment which would enable a simultaneous accomplishment of a whole range of economic and social goals. Incorporating both the constitutive principles (free prices, private property, the freedom of contracting, the openness of the market, the principle of the responsibility and consistency of the economic policy) and the regulatory principles (the strict competition policy, the labor market intervention, the internalization of external effects, the social policy measures and the provision of public goods), the SME model provides a potential framework in which economic and social problems are solved in the most efficient way.

The motivation for studying the SME model is manifold. The history of the economic thought, as well as economic history, may serve as a substitute for experimenting in real life, thus helping policy makers to avoid mistakes. On the other hand, this research also contributes to the relatively limited scope of research into the SME model in the Serbian-speaking area. The supremacy of the German economy at both the European and the global levels, whether with respect to the level of the GDP per capita or export results (Simonazzi, Ginzburg \& Nocella, 2013), or innovation performances, or the adaptability of the economic system, especially confirmed after the financial crisis (Storm \& Naastepad, 2015), suggests that this is a story about the specific economic system worth of being further investigated. The impressive evidence of economic excellence is the $\$ 5,000$ higher GDP per capita of those in the cradle of the industrial revolution, namely Great Britain! Such an outcome in an economic system is only possible to achieve over a long period of time. Therefore, the importance of the ideas which this system was built on and on which it still operates is apparent. The theoretical foundations of the SME model are found in the works of a number of authors, some of whom were active participants in the reconstruction of the German economy after WWII. Their particular role was in defining the institutional framework in which the market economy in Germany would be operating. Therefore, the story about the SME model brings together economic history and the history of the economic thought in a specific manner.

The request for the imposition of the competitive order (Wettbewerbsordnung) through the creation of a comprehensive institutional frame, which on its 
part has a decisive influence on the efficiency and adaptability of the economic system, is at the heart of the SME model, which is at the same time the subject matter of the research conducted in this paper as well. At the same time, we are speaking about the order since it implies not only the establishment of the market structures based on competition, but also the establishment and implementation of a whole range of the principles that enable an economy to operate efficiently.

In that sense, the paper is aimed at identifying the potential advantages, both economic and social, which the establishment of the competitive order brings with itself, and at determining the basic principles which are necessary to follow in the construction of the institutional structure, which on their part enable the establishment of this order, all this being done through an analysis of the original texts by using a qualitative analytical instrumentarium.

The hypothesis that will be tested in the paper is as follows:

$\mathrm{H}$ : From the point of view of the results achieved in the competitive order, the competitive order generates a high quality of economic performances and leads towards the resolving of a significant portion of the social problems that appear in society.

The competitive order stands for a superior alternative to the other (available) mechanisms of resource and income allocation. This may be inferred directly from the very definition of the SME model given by A. Rüstow (1960, 51), according to which "in the social-market economy, production and distribution are determined by the system of free prices through competition between (mainly private) enterprises, which is done far more productively, purposefully, in a fair manner, at a lower price and more reliably" compared with other market and nonmarket economic models. The SME model provides an efficient allocation of resources, as well as the elimination of poverty, and the avoidance of the wrong distribution of income (Karsten, 1985). The chosen topic is interesting not only from the point of view of the results generated by Germany, but also because the SME model was sharply criticized and caused skepticism in the period when its implementation began, especially by British economists. These criticisms, especially from today's perspective, are not supported by evidence. An additional reason for conducting this research lies in the close relationship between the ideas within the SME model and those of new paradigms in economics, such as the institutional economics, political economics, constitutional economics (Vanberg, 1988) or the Limited Access Order/Open Access Order (LAO/OAO)concept developed by D. C. North, J. J. Wallis, S. B. Webb and B. R. Weingast (Zweynert, 2015). In addition, there are various research studies in the domain of economic theory, as well as the numerous empirical studies, that found the link between (economic) freedom and economic growth (De Haan \& Sturm, 2000; Gwartney, Holcombe \& Lawson, 2004; Doucouliagos \& Ulubasoglu, 2006; Ivanović \& Stanišić, 2017). These findings represent the additional line of argumentation towards the validity and importance of the SME model. The reason for that lies in fact that freedom is of pivotal value in the SME model. It is a leading principle in building the institutional structure and an irreplaceable generator of economic progress.

The paper is structured into six parts. After the Introduction, the next three parts are dedicated to the analysis of the specific importance of the competitive order for generating efficient outcomes. The second part deals with the ways in which the competitive order stimulates economic agents towards a productive behavior, which results in an efficient allocation of resources. The third part addresses the issue of the significance of the competitive order in securing the (individual) freedom of economic actors in the broadest sense, which in turn affects the efficiency of the economic system as a whole. The fourth part is dedicated to the specific social benefits that the competitive order produces. As the SME model hinges on a clear and robust institutional structure, the fifth part focuses on identifying the requirements necessary for achieving such an order. In the Conclusion, the results of the research are summarized and the possible directions of future research are pointed out. 


\section{COMPETITION AS THE PERPETUUM MOBILE OF ECONOMIC EFFICIENCY}

One of the basic assertions within the SME model is that only the competitive order leads to efficient and sustainable social and economic outcomes. The especially visible link goes beyond competition and economic growth, and this relationship reflects "the relationship between a cause and a consequence" (Müller-Armack \& Erhard, 1972, 215).

Competition is generally observed as a situation in a specific market segment in which there are no restrictions either on the supply side or on the demand side (Böhm, 1961). A large number of agents on both sides of the market imply that exchange relations are governed and dominated by cooperation rather than by subordination. This aspect is vital for an efficient exchange. In real life, however, the number of participants on the supply side is much more important than the number of participants on the demand side. It is particularly significant regarding the amount of potential efficiency losses.

The problem of the egoism of economic agents is solved in the competitive order in the best manner. Competition hinders the destructive effect of egoism, simultaneously using its enormous potential by channeling the engagement of economic agents towards the most productive activities. As a consequence, the best alignment between individual and group interests is achieved (Nawroth, 1961; Böhm, 1942). Such an alignment is possible in the competitive order because economic agents have no power to influence the exchange process on the market. In such circumstances, egoism and a lack of the power of individual agents lead to a behavior characterized by self-compliance to prohibitions and, generally, to the rules of the game. It is also a prerequisite of a useful and rationally structured interaction and cooperation. As a consequence, transaction costs are reduced and economic efficiency is additionally stimulated.

The price system is the pivotal mechanism by which competition affects economic dynamics and determines economic agents' behavior. Only in the competitive order will the prices correctly direct economic agents' behavior. Prices are exogenously determined in the competitive order (Eucken, 1952). They are beyond the influence of any single agent. Economic activities and the planning of business operations are carried out on this basis. Prices are ex ante determined for all market participants and are not subject to change due to the action of any state or private instance or entity. If prices depended on the decisions of the state authorities or market participants' individual decisions, there would neither be security nor a justifiable assumption that such prices are appropriate. If they were the result of someone's will, they would inevitably lead to allocative inefficiencies. Such inefficiencies would be a consequence of the wrong basis on which economic agents would formulate a business strategy and make business decisions. As opposed to this, competitive constraints ensure that prices and costs are adequately linked, which leads to the business calculus which is highly exact (Röpke, 1961). The aforementioned exogenous character of prices does not mean that they stay unaltered over time. In fact, although monetary stability is one of the constitutive principles of an efficient economic system in the SME model, the variability of prices does not jeopardize this principle in any way as individual prices can go up and down, whereas the overall price level remains stable. In addition, competitive prices are essential for long-term cost alignment. They ensure that the prices of individual products are adjusted with the level of necessary costs in the short run and long run as well. The obvious advantage of such a price regime is especially evident if compared with the market structures characterized by the existence of an extra profit, where price responsiveness is far lower.

The main advantage of a flexible price regime within a competitive market structure reflects in producing relevant information for economic agents. A free price system corresponds to decentralized governance structures. Economic agents' needs will be the most efficient within the competitive order, under the given income and the availability of production factors (Lutz, 1962). Not only does competition lead to the cheapest and largest possible production, but it also makes economic agents constantly motivated to reduce costs. In real economic life, there is a 
constant differentiation of the needs on the demand side and competition compels economic agents on the supply side to constantly adjust themselves to this differentiation. This additionally ensures the adaptability of the system. The ultimate result of competitive pressure is not only the reduction of costs, but also a higher level of the product quality (Böhm, 1942).

The competitive order creates the stimulating structure of incentives that affects the engagement, actions. as well as reactions of economic agents towards the most productive economic activities. In this manner, complicated transactions are coordinated and regulated in the most efficient way. Exchange becomes well-structured and predictable. Economic agents' business calculus depends on the quality of business decision-making, and to a lesser extent on the external factors beyond their control. Creative engagement and an entrepreneurial initiative are in the best possible way awarded in such circumstances (Eucken, 1947). Since nothing is ex ante determined, all economic agents are maximally motivated to run for a better position on the market. Within the competitive order, the capabilities, ideas, and especially the efforts and abilities of the participants in the economic process are continuously contested (Stegmann, 1999).

Competition also provides the best framework for the adequate governance and the efficient use of capital. The competitive order gives the largest possible freedom to economic agents, which has to be accompanied by a proportional responsibility for the decisions they make. In such circumstances, the caution by investment decisions will be the largest. It is a prerequisite for a more efficient use of capital. A cautious approach to the market can only be ensured if business decisions are followed by the accountability of economic agents. According to W. Eucken $(1953,20)$ "whoever has the benefit must also bear the cost" of the economic activity. Responsibility for decisions and undertaking risk are adequately linked through that (Böhm, 1942). No less important is the fact that freedom has a sense only if it is coupled with responsibility (Eucken, 1953). The creative power of an order based on competition also stems from the fact that in such an order a large number of individuals are independent. It enables a high degree of self-determination and motivates economic agents to search their most productive engagement.

The maintenance of stability and the mitigation of a cyclical downturn are also the strengths of the competitive order. Competition forces economic agents to also constantly invest in the other entrepreneurial activities that ensure that their activities are always focused on the maximum possible performance. Such a behavior leads to necessary adjustments and raises necessary reagibility of the system as a whole.

The relationship between competition and technical progress is ambivalent. On the one hand, technical progress leads to the takeover of small enterprises by large companies. As a result, concentration rises on many markets. On the other hand, it contributes to the development of (product and service) substitutes, the expansion of the market, and an increased adaptability in the production process, as well as the expansion of the labor market. As a consequence, the flexibility and mobility of the factors of production and products in many markets are increased (Eucken, 2001). In addition, competition stimulates technical progress, as economic agents are compelled by competitive pressure not only to continuously innovate according to customer preferences, but also to seek to accelerate the implementation of innovative solutions (Symanski, 1999).

It is as well certain that competition causes certain losses, especially when those weaker on the market are concerned. However, even they attain net benefits from participation in the competitive process through many other advantages generated by the competitive order (Vanberg, 2002). Therefore, not only does competition provide an adequate system of rewards for those who are the most successful, but it also provides a sort of compensation for the less successful. For example, there would be no effect of learning or focus on innovation on the part of individual agents unless they were under competition pressure. Although no order is perfect, and thus neither competitive one, it has nevertheless accentuated superior in comparison with alternative market structures (Lutz, 1953). This above all concerns the efficiency of functioning, the quality of results and their sustainability. 


\section{FREEDOM AS THE STARTING POINT AND THE ULTIMATE OUTCOME OF THE COMPETITIVE ORDER}

Only in the competitive order can it be expected that the order, understood as the system of rules which creates the institutional structure, and freedom are in equilibrium. In such an order, there is no force that could jeopardize freedom. In the competitive order, the freedom of every economic agent is protected from the activities of those in power (Eucken, 1947). Another aspect of freedom enshrined in the competitive order relates to the fact that an individual is free to act in accordance with his/her own interests and according to his/her own personal judgment (Müller-Armack \& Erhard, 1972). It is the key requirement for an efficient exchange.

The point of departure in the relationship between freedom and economic efficiency in the SME model starts from freedom. The reversibility of the relationship is, in the best case, the fact of secondary importance. The significance is, therefore, in the welfare benefits of freedom (Böhm, 1961), not in the impact of prosperity on freedom. In that sense, the best way to create an economic value is to establish and protect freedom. Ensuring freedom through competition means securing growth in the economy (Müller-Armack \& Erhard, 1972). The freedom provided by the competitive order is first and foremost intangible value (Böhm, 1942), securing it is a decisive requirement in enhancing economic efficiency.

The freedom inextricably related to the existence of the competitive order is also the main argument for the supremacy of this order in relation to the alternative forms of the organization of economic life. The competitive order ensures the freedom of planning for all economic agents. Under such conditions, the minimum resistance from and the violation of the rules are expected. There is no third party able to influence unilateral and arbitrary (inefficient) prices. As economic agents are free to plan their activities, also bearing responsibility for them, which is underpinned by market and institutional sanctions, the violation of the rules of the game is expected to be minimal. Such a behavior leads to the minimization of transaction costs, an increase in the volume and number of transactions and the deepening of business relationships amongst economic agents.

The competitive order provides the highest level of the freedom of choice for both consumers and manufacturers. As competition fosters exchange relations, it also contributes to the peaceful resolution of disputes on the market. This aspect heavily relies on the price system. The price system in the competitive order implies that everyone freely decides how to use their own resources. There is no one in a position to force someone else to make decisions in a certain way. Reliance on prices is entirely based on the freedom of decision-making (Böhm, 1950). Although coordination shapes relationships between economic agents and although the freedom of individual actors is at the heart of such relationships, freedom is not absolute. Economic agents are faced with a limited (but not small) number of the business choices and behavioral options defined by the rules of the game. Furthermore, economic actors are not absolutely free because their actions depend on the behavior of other actors. They have to take into account the interests and behavior of other economic agents in order to be successful in their entrepreneurial activities. Although freedom is limited in the aforementioned way, it is far greater than the freedom available to economic actors in alternative market structures. Therefore, freedom does not imply freedom from (any) rules that are a condition for well-governed and structured transactions.

Competition is not only a prerequisite for the broadest and universally understood freedom of the individual, but it is also the assumption that some rights that constitute the guarantee of liberty do not deviate from and do not transform into the means of power. This particularly applies to the freedom of contracting. The freedom of contracting is essential for economic efficiency and the competitive order is irreplaceable when the preservation of the essence and nature of this freedom is concerned. The reason for this is that the very principles of the freedom of contracting depend on the economic and market order based on competition. Competition prevents the abuse of the freedom of contracting by restricting 
the freedom of the parties in contractual relations (Eucken, 1953). The principle of freedom does not allow the abuse of power with the aim of narrowing down the freedom of the parties in a transaction. For that very reason, the meaning of the freedom of contracting is far beyond the formal legal meaning of its content.

The competitive order is directly related to the individual aspects of freedom, such as the freedom of contracting. However, the efficiency of the economic system is in the long run determined by the degree of freedom in the broadest sense. This arises from the fact that there is a close interconnection between different domains of freedom. Safeguarding one aspect requires the existence of another aspect. For example, the freedom of entrepreneurial engagement is a precondition for the consumer's freedom to choose (Müller-Armack \& Erhard, 1972).

The competitive order is a precondition for the functionality of private law. Formal (legal) rules define relationships, responsibilities and the terms of exchange between equal parties in a transaction. These parties do not possess political power or social privileges in relation to one another (Böhm, 1966). Competition also works preventively against the establishment of political power. As such, it is compatible with both democracy and the legal order based on it. Relying on market forces, securing the functionality of the legal order and limiting state interventionism that would have consequences for restricting freedom (Böhm, 1961), the competitive order ensures the highest degree of economic efficiency. By limiting state interventions, competition preserves the autonomy of economic agents and thus the allocation of both production resources and (free) consumer decisions. For this reason, the competitive order is, by its very nature, a democratic mechanism.

\section{SOCIAL BENEFITS IN THE COMPETITIVE ORDER}

The mere fact that a competitive order is considered to be the most efficient of all of the other alternatives poses the issue of the consequences it produces in the social domain. The social benefits of the competitive order are of particular importance in the circumstances of an economic system facing difficulties. In these circumstances, there is an especially evident claim that what contributes to productivity growth has much more of a social than of an economic value (Stegmann, 1999). The social value of the competitive order should primarily be considered in this context. The market is unable to produce desirable social outcomes if the competitive order does not function adequately. Thus, the competitive order is per se a precondition for solving a significant part of the problems that arise in the social sphere. The need for relaying on competition in the distributive domain arises from yet another assumption within the SME model: it is impossible to find a universal (material) indicator of justice. For each distribution, there is a danger that it will be influenced by the forces that will draw the distribution away from the principle that everyone has what he deserves according to the effort he has made. This principle tends to be materialized automatically in the competitive order (Lutz, 1953).

Within the competitive order, the largest and most diversified production is provided in the long term, which does not restrict the participation of any individual. Participation in the overall economic success of the national economy is also realized through the better accessibility and quality of public goods and services, job opportunities for employees or salary rises. The competitive order creates the framework in which the material basis of society develops in such a way that the existing social problems can be largely solved by such development. By providing a large number of opportunities to different individuals, regardless of their social background, it contributes to greater mobility and social cohesion. Since the existence of the competitive order implies the absence of power, the exploitation of individuals is largely hampered. The competition contributes to solving social problems "in the spirit of freedom" (Eucken, 1953, 24). Competition forces economic agents to react promptly, whether it is the question of solving problems or exploiting business opportunities. This may also be seen as a kind of the (economic) advantage that has a social character 
because "he who reacts promptly helps twice" (Müller-Armack \& Erhard, 1972, 280).

Since the competitive order rests on coordination rather than on subordination (Lutz, 1971), the terms of exchange between economic agents take place freely, which implies the relaxation of social relations and contributes to conflict mitigation. Coordination allows continuous adjustment regarding entrepreneurial plans. In this respect, coordination is a mechanism for regulating interpersonal relations in the sphere of trade and production. The mitigation of social conflicts in the competitive order also refers to the fact that such a structure contributes to the growth of wages for the majority of the population (MüllerArmack, 1962). Although a higher level of income is an explanation of economic agents' motivation mechanism and consequently of economic efficiency in general, its importance also reflects in the fact that it simultaneously contributes to the greater social recognition of the individual who achieves it. A higher level of income is a confirmation of an individual's work effort (Symanski, 1999).

The competitive order is based on the idea of justice arising from the fact that economic agents do not have power. In such an order, everyone is rewarded according to their contribution. If the balance of power changes in the sense that there is a significant asymmetry of power in the system, the system of relative prices and generally the efficiency of the economic system tend to be distorted. Not only are prices in such a system not a good basis for a business calculus, but the very idea of equity is also undermined by the nature of the decisions of those in possession of power. Opposite to that, prices in the competitive order prevent the formation of inefficient institutional structures by motivating economic actors to make continuous efforts and adjustments. It promotes the self-responsibility of all economic agents and supports efforts towards the continued efficiency of the economic process. This is also an explanation of the reasons why the principle of competition is seen as the core cause of social, economic and social progress. It has equal importance and equally tangles all of the members of a society, from entrepreneurs to all other professions. Prices in a competitive system reflect a necessity, fairness and rationality (Böhm, 1947), making it an indispensable element of both economic efficiency and the precondition of equity in the system. The prices formed on the competitive market cannot be misused by any participant in the economic process. There is no individual will that determines them, but rather a certain collective will, which prescribes how and at what level they should be. However, they have a compelling effect and all participants in the economic process must adhere to them. This effect is a result of numerous, equal, free and spontaneous reactions following exchange. Due to that, competitive prices have no influence on political, social and economic freedoms.

As the competitive order denotes a state of the absence of restrictions on participation in a particular economic process, all those who participate or seek to participate in it have equal chances for achieving a success. Only under these assumptions, i.e. the absence of restrictions on entering and exiting the market, is it possible to expect all advantages from competitive structures (Kersting, 2010).

A reduction in costs in production is one of the significant impacts of competition in the social sphere. In the long run, every economic agent is forced to minimize his/her costs in order to survive. Consequently, products are cheaper. When cost reduction on a wider scale is in question, there is also a decrease in prices in an appropriate range. So, the benefits of reducing costs are not only attributable to the producer, but partly to the consumer as well. This leads to the socialization of economic progress without the use of legal coercion.

Although the competitive order generates many social and economic advantages, its fruition requires a political and ideological support. It needs to provide the long-term climate that protects and promotes such an order (Böhm, 1961). Economic agents' believing in themselves and their own power in a continuously changing environment occupies the central place in understanding certain prerequisites of the competitive order. Such attitudes of economic agents, together with the power of competition, provide such economic agents' mobility and a continued quest for 
their most productive engagement. No less important characteristic attributed to economic agents is the attitude of individuals towards monopolies and other alternatives of the competitive order (Böhm, 1942). This is especially important because the attitudes and preferences of individuals determine the space in which the (formal) institutional structure is created and in general the overall political process takes place.

\section{INSTITUTIONAL PREREQUISITES FOR THE DEVELOPMENT OF THE COMPETITIVE ORDER}

Within the framework of the SME model, there are basically three fundamental preconditions that could be identified as the prerequisites for the competitive order, and thus for the achievement of the advantages that this order brings. The list of the requirements is much broader, but these three conditions are pivotal.

According to the first, an economy should be open as much as possible. The competitive order is not conceivable within an autarchic economy. The highest degree of market openness must be an imperative and should be the guideline principle in shaping the economic policy (Eucken, 1952). An exception to this rule is the situations where foreign competitors are subsidized by the state and as such represent unfair competition. The importance of foreign trade is not only reflected in competitive pressures on domestic economic agents, but also in the fact that the competitive order cannot be fully developed without an adequate inclusion in the international division of labor. Only by the inclusion in the world economy will the fundamental incentives provided by competition be secured. Hence, it is not only the pressure foreign competitors provide in the internal market, but also the appearance of domestic producers in the foreign market, that provides irreplaceable incentives for overall efficiency in an economy.

The incentives resulting from competition exceed the immediate impact on the economic agents exposed to them. They are of decisive significance for the overall market. Competition influences the parties who are only indirectly related with those who are directly competing. For example, suppliers will be strongly influenced to innovate and lower their costs in order to maintain contracts, although they are not under direct competitive pressure. In addition, market openness could be a significant factor in the stability of prices in the national economy. In this regard, the competitive order based on a free-price regime cannot be imagined without market openness.

The narrowing of the (specific) market through the protection policy in the domain of foreign trade not only results in the impact on the market segment which is under such measures, but also produces significantly wider consequences. Protection itself is a significant prerequisite for the creation of asymmetric power positions in exchange. In addition, such a policy distorts the links between individual markets, as the narrowing of one market automatically leads to the narrowing of other markets, too (Eucken, 1952). In the case of the distortion of the links between individual markets, the market system as a whole will not function in an efficient way. Closing the market works against one of the constructing principles in the SME concept: the interdependence of orders (Interdependez der Ordnungen). There is a misallocation of resources. If the part of a market that is protected makes a significant part of the overall economic system, the effects on other orders can be particularly strong. It is especially true for the legal or political system (Eucken, 2001). Inefficiencies are caused by the phenomenon of rent-seeking, or the influence of interest groups, when the institutions of the political and legal systems are shaped according to the interests of certain groups, rather than being driven by the efficiency of the economic system as a whole.

The second request refers to private property. A successful market system is based on private property (Müller-Armack \& Erhard, 1972). Private property represents a structural right and a fundamental prerequisite for the efficiency of the entire order (Nawroth, 1961). Based on this very fact, compatibility between private property and the competitive order is unequivocal. However, the impact that goes from competition to private property is of great importance as well. The competitive order is the only one that 
secures the (highest) social value of private property. It also contributes to its legitimization (Rüstow, 1960). Competition is an irreplaceable instrument for controlling private property (Eucken, 1953). The mere existence of the competitive order implies a high degree of the dispersion of ownership in an economy (Böhm, 1942).

Private property is not only a feature of the competitive order. It is also a prerequisite of individual freedom. Private property is a warranty of individual freedom in two ways. First, private property protects individuals by providing a guarantee for the independence of their decisions and the responsibilities vis-à-vis other agents in the economic process. Second, it protects individuals from the state and its coercive monopoly (Röpke, 1957). On the contrary, in the absence of the competitive order, private property may become an instrument of restricting freedom, generating rents and may generally lead to disruption in the economic process and serious social costs (Eucken, 1952). Thus, the competitive order enables the use of private property in an efficient way and prevents its abuse. Private property brings a greater predictability for the parties to transactions, as well as greater security for its owners. In this sense, entering into a transaction will be facilitated if a business partner has assets. It implies the absence of the influence of a third party in business relations not directly involved in the transaction. Likewise, the business activities that are covered by the assets provide a higher degree of safety to the titular by providing greater responsiveness to change in market conditions. Such a type of responsiveness may to a large extent be narrowed if business activities are financed by a third party. Private property is a precondition not only for freedom, but for responsibility as well. If private property is a guarantee for decisions made by economic agents, then it will also be an important instrument affecting the allocation of resources (Lutz, 1962).

The third request refers to the rule of law. It is the key mechanism for protecting the competitive order, and consequently economic efficiency and productivity growth (Stegmann, 1999). It is only the state that may ensure adherence to the rule of law by providing equality before law for all. The decision on the model of a legal order is the most important decision regarding an institutional structure (Lutz, 1971). A reverse causality also appears between the rule of law and the competitive order: the ability of the state is determined by the presence of the competitive order (Nawroth, 1961). Interdependenz der Ordnungen is especially visible between the state and the economic order.

The rule of law provides double protection for economic agents. The rule of law ensures the protection of an individual from the state or a coercive authority. An individual is protected by creating an institutional structure that clearly specifies the procedures and ways of state intervention, taking into account the preservation of the maximum level of freedom and protection of the individual. These procedures exclude the arbitrary and ad hoc treatment of state authorities. Many of these aspects are normatively regulated by the Constitution and are operative by solutions within administrative law. The second level of protection refers to the protection provided by a legal order to individuals in relation to other parties in an exchange. This aspect gains in importance especially in the situations characterized by the asymmetric relations of power (Eucken, 2001). A possibility of disrupting the exchange relationship is twofold. First, the one with power is able to directly determine the terms of exchange. Second, the agent with power may be able to influence the content of the rules created in the political process. Only in a situation where there is a symmetry of power is an individual forced or even able to achieve his/her goal by only taking into account the interests of (all of) the parties in the transaction (Nawroth, 1961). In this situation, the maximum freedom of each individual is guaranteed. Steadiness and impersonality are the features of the good rules underpinning an individual's freedom (Böhm, 1942). In addition, the rule of law also provides protection against interest groups. Thus, the rule of law protects the freedom by controlling the political and/or economic power of an individual or a group (Gutmann, 1991). Protecting an individual's freedom from the state and from the abuse of freedom by those who have power, the rule of law creates conditions for the emergence and survival 
of the competitive order. In a system where there is an abuse of power by an individual and/or interest groups, as well as unregulated state intervention, the competitive order cannot arise, and, even if it exists, the same cannot survive (Müller-Armack \& Erhard, 1972).

\section{CONCLUSION}

One of the basic assumptions within the SME model is that the competitive order leads to efficient and sustainable economic and social outcomes. It does so in a better way than other market and non-market orders. The competitive order motivates economic agents to engage in the most productive activities, causes a reduction in transaction costs and enables mutually beneficial and rationally structured interactions and cooperation amongst them. Competitive constraints ensure that prices and costs are adequately linked, which makes the business calculus of economic agents exact to the greatest extent. Not only does competition lead to the cheapest and largest possible production, but it also makes economic agents constantly motivated to reduce costs. In addition to cost adjustment, competition makes it necessary for economic agents to adapt to the constant differentiation of needs on the demand side of the market. It consequently leads to a higher quality of products. Greater adaptability, as well as an innovative economy are the end result. In such a system, there are continuous changes followed by the fast implementation of innovative solutions.

Freedom is the leading feature following the activities undertaken by economic agents, but it has a(n) (economic) value only if it is followed by economic agents' responsibility. Freedom leads to progress only if economic agents bear responsibility for the decisions they make. The creative power of competition stems from the fact that, in such a system, a large number of individuals are independent. It enables a high degree of self-determination. Consequently, selfdetermination encourages a constant search for productive engagement.
Not only does the competitive order ensure freedom and encourage the productive behavior of economic agents, but it also produces significant social benefits. In accordance with the basic postulates within the SME model, everything that contributes to productivity growth is of great social importance. This aspect is of particular importance in the periods of economic downturns. The competitive order also provides a generally acceptable distribution of income. The social benefits of the competitive order are also reflected in a series of other results: it makes possible the largest and the most diverse production, the better accessibility and quality of public goods and services, better and plentiful job opportunities, and rising wages for the majority of the population as well. In such an order, the accent is on results. They are continually questioned, so individuals move upwards and downwards. As a consequence, the competitive order leads to greater social mobility. The system that provides everyone with the same chances implies a far higher degree of social cohesion and acceptability for the broadest population.

The attainment of effective social and economic outcomes implies the existence of an adequate institutional environment, in which such results are possible. It is imperative that there should be the highest degree of market openness, which, as a principle, must be incorporated in all of the domains of the economic policy. The competitive order is impossible without clearly defined proprietary rights. The competitive order lies de facto on the dominant importance of private property. Its significance reflects in strong incentives by economic agents towards the preservation of and increasing the value of property, and in providing greater security and predictability for parties in transactions. Private property provides an efficient allocation of resources, as well as certainty and the lowest obstacles when its use and entry into business transactions are concerned. However, if the institutional structure does not consistently protect what the competitive order requires, namely the freedom and responsibility of economic actors, among other things, it will consequently lead to deviations in exchange and efficiency will be distorted. If the institutional structure is weak, the individuals or groups that have economic power tend to socialize 
losses and/or make gains thanks to the market position, rather than the competitiveness of the product or the service they offer. For this reason, the existence of the rule of law is the crucial precondition. The rule of law makes everyone equal before the law, deprives everyone of a privileged position and prevents rent seeking and the socialization of losses after the promulgation of wrong business decisions.

There are several possibilities of further research. The one concerns the possibility of further research study of the constitutive principles of the SME model and the relationship between them in the establishment of the competitive order. In addition to this, as the competitive order sometimes produces undesired consequences, the SME model provides certain principles which should underpin an institutional framework with the aim of mitigating them. These are regulatory principles. The significance, content and implications of these principles represent a potentially interesting field of research. A particularly interesting study would concern the rule of law and its importance and meaning for efficient exchange. In addition, it would be fruitful to analyze the cases that involve a deviation from competitive market structures and finding ways of preventive actions against the establishment of asymmetric market relations. Furthermore, the empirical analysis of the individual aspects of the SME model could represent an additional inspiration for future research. Particularly interesting would be the analysis of the similarities between the institutional economy and the SME model. An additional reason for this may be the fact that the founding fathers of the SME model sharply criticized classical economic theory, whereas institutionalists sharply criticized certain limitations of neoclassical economic theory. The future directions of the research are also the most important constraints of this paper, and they include reliance solely on theoretical analysis, the missing link between theoretical assumptions and the degree of their operationalization in the functioning of the German economy, and, possibly, the empirical valorization of the SME model in a comparative context.

\section{REFERENCES}

Berger, H. (2006). Optimal central bank design: Benchmarks for the ECB. The Review of International Organizations, 1(3), 207-235. doi:10.1007/s11558-006-8344-8

Böhm, F. (1942). Die Gesellschaftskrisis der Gegenwart. ErlenbachZürich, Switzerland: Eugen Rentsch Verlag.

Böhm, F. (1947). Kartelauflösung und konzernentflechtung. Spezialistenaufgabe oder schicksalsfrage? In T. Roser, \& W. Oswalt (Hrsg.). Entmachtung durch Wettbewerb, 2007, (pp. 59-91). Münster, Bundesrepublik Deutschland: LIT Verlag.

Böhm, F. (1950). Wirtschaftsordnung und Staatsverfassung. Tübingen, Bundesrepublik Deutschland: Verlag J. C. B. Mohr.

Böhm, F. (1961). Demokratie und Ökonomische Macht. (Sonderdruck) Karlsruhe, Bundesrepublik Deutschland: Müller Verlag.

Böhm, F. (1966). Privatrechtgesellschaft und Marktwirtschaft. ORDO - Jahrbuch für die Ordnung von der Gesellschaft und Wirtschaft, 17, 75-151.

De Haan, J., \& Sturm, J. E. (2000). On the relationship between economic freedom and economic growth. European Journal of Political Economy, 16(2), 215-241. doi.org/10.1016/S01762680(99)00065-8

Doucouliagos, C., \& Ulubasoglu, M. A. (2006). Economic freedom and economic growth: Does specification make a difference? European Journal of Political Economy, 22(1), 60-81. doi.org/10.1016/j.ejpoleco.2005.06.003

Erhard, L. (1961). Deutsche Wirtschaftspolitik - Der Weg der Sozialen Marktwirtschaft. Düsseldorf, Bundesrepublik Deutschland: Econ-Knap.

Eucken, W. (1947). Über die zweifache wirtschaftspolitische Aufgabe der Natinalökonomie. In N. Goldschmidt, \& M. Wohlgemuth (Hrsg.). Grundtexte zur Freiburger Tradition der Ordnungsökonomik, 2008, (pp. 133-155). Tübingen, Bundesrepublik Deutschland: Mohr Siebeck.

Eucken, W. (1952). Grundsätze der Wirtschaftspolitik. Tübingen, Bundesrepublik Deutschland: J. C. B. Mohr.

Eucken, W. (1953). Wettbewerb, Monopol und Unternehmer. Bad Nauheim, Bundesrepublik Deutschland: Vita Verlag. 
Eucken, W. (2001). Wirtschaftsmacht und Wirtschaftsordnung Londoner Vorträge zur Wirtschaftspolitik und zwei Beiträge zur Antimonopolpolitik. Münster, Bundesrepublik Deutschland: LIT Verlag.

Gutmann, G. (1991). The intellectual basis and historical development of social market economy. In W. Jung (Ed.). Social market economy: An economic system for developing countries (pp. 13-52). Sankt Augustin, Bundesrepublik Deutschland: Academia Verlag Richarz.

Gwartney, J. D., Holcombe, R. G., \& Lawson, R. A. (2004). Economic freedom, institutional quality, and cross-country differences in income and growth. Cato Journal, 24(3), 205233.

Hielscher, K., \& Markwardt, G. (2012). The role of political institutions for the effectiveness of central bank independence. European Journal of Political Economy, 28(3), 286-301. doi:10.1016/j.ejpoleco.2011.08.004

Hillebrand, R. (2015). Germany and its Eurozone crisis policy: The Impact of the country's ordoliberal heritage. German Politics and Society, 33(1), 6-24. doi.org/10.3167/ gps.2015.330102

Ivanović, V., \& Stanišić, N. (2017). Monetary freedom and economic growth in new European Union member states. Economic research, 30(1), 453-463. doi:10.1080/133167 7X.2017.1305803

John, K. D. (2007). The German social market economy - (Still) a model for the European Union? Theoretical and Applied Economics, 3(508), 3-10.

Karsten, S. G. (1985). Eucken's 'social market economy' and its test in Post-War West Germany: The economist as social philosopher developed ideas that parallelled progressive thought in America. American Journal of Economics and Sociology, 44(2), 169-183. doi.org/10.1111/j.1536-7150.1985. tb02331.x

Kersting, W. (2010). Marktwirtschaft, staat und soziale gerechtigkeit. In W. Kersting (Hrsg.). Freiheit und Gerechtigkeit - die moralischen Grundlagen der Sozialen Marktwirtschaft (pp. 45-62). Frankfurt am Main, Bundesrepublik Deutschland: Peter Lang.

Loungani, P., \& Sheets, N. (1997). Central bank independence, inflation, and growth in transition economies. Journal of Money, Credit, and Banking, 29(3), 381-399.
Lutz, F. A. (1953). Einwände gegen die Wettbewerbsordnung - ein Gespräch mit studenten. ORDO - Jahrbuch für die Ordnung von Wirtschaft und Gesellschaft, Bd. 5, 245-266.

Lutz, F. A. (1962). Geld und Währung - gesammelte Abhandlungen. Tübingen, Bundesrepublik Deutschland: J. C. B. Mohr.

Lutz, F. A. (1971). Politische Überzeugungen und Nationalökonomische Theorie - Züricher Vorträge. Tübingen, Bundesrepublik Deutschland: J. C. B. Mohr.

Müller-Armack, A. (1962). Das gesellschaftspolitische Leitbild der Sozialen Marktwirtschaft. In E. Tuchtfeldt, \& E. Dürr (Hrsg.). Genealogie der Sozialen Marktwirtschaft: Frühschriften und weiterführende Konzepte, 1981, (pp. 146-162). Stuttgart, Bundesrepublik Deutschland: Verlag Paul Haupt.

Müller-Armack, A., \& Erhard, L. (1972). Soziale Marktwirtschaft, Ordnung der Zukunft: Manifest '72. Frankfurt am Main, Bundesrepublik Deutschland: Ullstein.

Nawroth, E. E. (1961). Die sozial - Und wirtschaftsphilosophie des neoliberalismus. Heidelberg, Bundesrepublik Deutschland: F. H. Kerle Verlag.

Röpke, W. (1957). Eigentum als Säule einer freien Gesellschaft. Schweizer Monatshefte, 37(6), 441-447.

Röpke, W. (1961). Marktwirtschaft und ordnung des wettbewerbes. In J. Höffner, A. Verdross, \& F. Vito (Hrsg.). Naturordnung in Gesellschaft, Staat, Wirtschaft (pp. 624-631). Innsbruck, Republik Österreich: Tyrolia-Verlag.

Rüstow, A. (1960). Das christliche gewissen und die soziale marktwirtschaft des neoliberalismus. Junge Wirtschaft: Zeitschrift für fortschrittlichen Unternehmertum, 2, 46-52.

Simonazzi, A., Ginzburg, A., \& Nocella, G. (2013). Economic relations between Germany and Southern Europe. Cambridge Journal of Economics, 37(3), 653-675. doi. org/10.1093/cje/bet010

Stegmann, F. -J. (1999). Social market economy and morality Contradictory or complementary. Johannesburg, Republic of South Afrika: Konrad-Adenauer-Stiftung.

Storm, S., \& Naastepad, C. W. M. (2015). Crisis and recovery in the German economy: The real lessons. Structural Change and Economic Dynamics, 32(C), 11-24. doi.org/10.2139/ ssrn.2638053 
Symanski, T. (1999). Die Mittelstandsorientierung in der Konzeption der Sozialen Marktwirtschaft - mit einer kritischen Betrachtung der deutschen Wirtschafts - und Gesellschaftslage. Marburg, Bundesrepublik Deutschland: Tectum Verlag.

Vanberg, V. (1988). Ordnungs theorie as constitutional economics - The German conception of a Social Market Economy. ORDO: Jahrbuch für die Ordnung von Wirtschaft und Gesellschaft, 39, 17-31.

Vanberg, V. (2002). Soziale Sicherheit, Müller-Armacks "Soziale Irenik" und die ordoliberale Perspektive. In R. H. Hasse, \& F. Quaas (Hrsg.). Wirtschaftsordnung und Gesellschaftskonzept: Zur Integrationskraft der Sozialen Marktwirtschaft (pp. 227-259). Bern, Switzerland: Verlag Paul Haupt.
Wrobel, R. M. (2012). The social market economy as a model for sustainable growth in developing and emerging countries. Economic and Environmental Studies, 12(1), 47-63.

Wrobel, R. M. (2014). Cambodia's transition to sustainable development: Preconditions, recommendations, obstacles. Central and Eastern European Journal of Management and Economics (CEEJME), 2(2), 71-92.

Zweynert, J. (2015). The concept of Ordnungspolitik through the lens of the theory of limited and open access orders. Constitutional Political Economy, 26(1), 4-18. doi:10.1007/ s10602-014-9173-z

$$
\begin{array}{r}
\text { Received on } 28^{\text {th }} \text { June } 2018, \\
\text { after revision, } \\
\text { accepted for publication on } 22^{\text {nd }} \text { August } 2018 \\
\text { Published online on } 27^{\text {th }} \text { August } 2018
\end{array}
$$

Vladan Ivanovic is assistant professor at the Faculty of Economics University of Kragujevac. He obtained his PhD at the Faculty of Economics University of Kragujevac. Currently he is doing the second PhD at the University of Hohenheim, Stuttgart, Germany. His areas of interest are economic policy, public policies and institutional economics. 


\title{
OD PORETKA DO PROSPERITETA: ZNAČAJ KONKURENCIJE U MODELU SOCIJALNO-TRŽIŠNE PRIVREDE
}

\author{
Vladan Ivanović* \\ Ekonomski fakultet Univerziteta u Kragujevcu
}

Traganje za ekonomskim uspehom, izgradnjom institucionalne strukture koja će obezbediti efikasno funkcionisanje ekonomije, spada u srž praktičnih aktivnosti koje preduzimaju vlade širom sveta, ali i akademskih istraživanja koja nastoje objasniti uspeh pojedinih nacionalnih ekonomija. Superiornost rezultata koji ekonomija Savezne Republike Nemačke (SRN) ostvaruje u evropskim okvirima, ali i globalno, od nivoa GDP-a per capita do visoke produktivnosti, inovativnosti i izvoznih performansi, čine osnovnu motivaciju za ovo istraživanje. Naime, kako se do ekonomskog uspeha, za razliku od neuspeha, uvek dolazi u dugom vremenskom periodu, cilj istraživanja je da ukaže na (istorijske) institucionalne korene koji leže $\mathrm{u}$ uspehu savremene privrede SRN. U tom kontekstu, analiziran je model Socijalnotržišne privrede, odnosno, značaj konkurentskog poretka kao nosećeg mehanizma alokacije, bez kojeg nije moguća izgradnja efikasnog tržišnog sistema. Shodno tome, ključni rezultati istraživanja odnose se na identifikovanje ekonomskih i socijalnih prednosti koje uspostavljanje konkurentskog poretka u modelu Socijalno-tržišne privrede podrazumeva, kao i institucionalnih pretpostavki u kojima je takav poredak moguć.

Ključne reči: Socijalno-tržišna privreda, nemački model, konkurencija, ekonomska efikasnost, institucije

JEL Classification: B25, B52, P10

\section{UVOD}

Ekonomska istorija obiluje primerima pokušaja reformisanja ekonomskih sistema, ali je malo onih koji su bili uspešni. Iako se za većinu danas razvijenih zemalja njihov razvoj može posmatrati kao evolutivni put, retko ili nikada prekidan radikalnom

* Korespondencija: V. Ivanović, Ekonomski fakultet Univerziteta u Kragujevcu, Đ. Pucara 3, 34000 Kragujevac, Republika Srbija; e-mail: vivanovic@kg.ac.rs društvenom, političkom ili ekonomskom promenom, postoje izuzeci. Jedan od tih izuzetaka jeste i Socijalno-tržišna privreda (STP) Savezne Republike Nemačke (SRN). Odlučujući trenutak nastanka ovog modela vezuje se za monetarnu reformu u Zapadnoj Nemačkoj 1948. Način na koji je došlo do transformacije i principi kojima je ona bila oblikovana bili su, $\mathrm{u}$ velikoj meri, suprotnost $\mathrm{u}$ odnosu na dominantne obrasce razvoja koji su karakterisali ostale zemlje Zapada i koje su u posleratnom periodu 
svoj razvoj bazirale na intenzivnoj i ekstenzivnoj državnoj intervenciji i uticaju na ekonomske procese. Osim toga, reč je o radikalnoj promeni celokupnog sistema, ne samo u odnosu na period od dolaska socijal-nacionalista na vlast, već i u odnosu na period pre 1933, odnosno, doba Vajmarske republike. Naime, i u tom periodu privreda Nemačke bila je suočena sa sistemskim nedostacima i opterećena brojnim socijalnim i ekonomskim problemima, a dolazak nacional-socijalista na vlast pa se, dobrim delom, može objasniti i slabošću sistema iz prethodnog perioda.

Ideje na kojima počiva STP imale su, i imaju, veliki uticaj na institucionalni dizajn $u$ određenim oblastima kod brojnih zemalja i supranacionalnih organizacija. Na primer, institucionalna rešenja, posebno ona koja su se odnosila na izrazito visok stepen nezavisnosti centralne banke SRN, imala su uticaj na institucionalna rešenja koja su primenjena u tranzicionim ekonomijama (Loungani \& Sheets, 1997), ali i u razvijenim zemljama, poput Velike Britanije (Hielscher \& Markwardt, 2012). Naročito značajan je bio uticaj na institucionalni dizajn evropskih monetarnih institucija, odnosno, na institucionalne karakteristike Evropske centralne banke (Berger, 2006). S druge strane, brojni izazovi sa kojima se suočavaju zemlje u razvoju i brzo rastuće privrede, a naročito s obzirom na dosadašnje neuspehe (većine njih) i na nove rizike nastale pojavom finansijske i ekonomske krize 2008, model STP može predstavljati značajan alternativni pristup daljem razvoju ovih zemalja (Wrobel, 2012). Neki autori (John, 2007; Hillebrand, 2015), ukazuju i na potencijalni značaj modela STP za redizajniranje institucija na kojima počivaju ekonomske i socijalne politike na nivou EU. To posebno dolazi do izražaja ukoliko se ima u vidu da EU, shodno osnivačkim ugovorima, počiva na otvorenoj tržišnoj ekonomiji i slobodnoj konkurenciji, a što su konstrukcioni mehanizmi STP modela. Potencijal STP se ogleda i u sveobuhvatnosti kojom se tretira ekonomska stvarnost (Wrobel, 2014), čime se na adekvatan način može kreirati institucionalni ambijent koji doprinosi simultanom ostvarivanju čitavog niza ekonomskih i socijalnih ciljeva. Kao integralni koncept, koji počiva na konstitutivnim principima (slobodne cene, privatna svojina, sloboda ugovaranja, otvorenost tržišta, princip odgovornosti, i konzistentnost ekonomske politike), ali koji inkorporira i niz regulatornih principa (striktna politika konkurencije, intervencija na tržištu rada, internalizacija eksternih efekata, određene mere socijalne politike, i obezbeđivanje javnih dobara), STP može doprineti konstituisanju ekonomskog sistema u kojem se na najefikasniji način rešavaju ekonomski i socijalni problemi.

Motivacija za proučavanje modela STP je višestruka, pre svega, činjenica da istorija ekonomske misli, ali i ekonomska istorija, može poslužiti kao supstitut eksperimentisanju, a time i greškama, mnogim nacionalnim ekonomijama koje tragaju za sopstvenim putevima razvoja. Istovremeno, ovo istraživanje je prilog relativno ograničenom obimu istraživanja na ovu temu, posebno u srpskom akademskom prostoru. Osim toga, superiornost rezultata koje privreda SRN generiše u evropskim, ali i svetskim okvirima, od nivoa GDP-a per capita, preko izvoznih rezultata (Simonazzi, Ginzburg \& Nocella, 2013) i inovacionih performansi, pa do adaptabilnosti i reagibilnosti, koja je naročito potvrđena kroz brz i snažan oporavak nakon krize iz 2008 (Storm \& Naastepad, 2015), sugeriše da je reč o specifičnom sistemu. Upečatljiv dokaz za to je i danas za 5000\$ veći GDP per capita $\mathrm{u}$ odnosu na Veliku Britaniju, kolevku industrijske revolucije. Takav rezultat $\mathrm{u}$ jednom ekonomskom sistemu moguć je samo u dugom vremenskom periodu, pa su utoliko značajnije ideje na kojima je taj sistem nastao i na kojima danas počiva. Teorijske osnove modela STP nalaze se $u$ radovima niza autora, a kasnije i aktivnih učesnika u izgradnji i obnovi privrede SRN, a posebno u definisanju institucionalnih okvira $\mathrm{u}$ kojima se ova privreda razvijala.

U srži modela STP jeste zahtev za uspostavljanjem konkurentnog poretka (Wettbewerbsordnung), kroz kreiranje sveobuhvatnog institucionalnog okvira, a što ima odlučujući uticaj na efikasnost i adaptabilnost ekonomskog sistema, što je ujedno i predmet istraživanja u ovom radu. Pritom, reč je o poretku, jer on podrazumeva ne samo uspostavljanje tržišnih struktura baziranih na konkurenciji, već uspostavljanje i implementaciju čitavog niza principa koji omogućuju da privreda funkcioniše efikasno. 
U tom smislu, cilj rada je da se analizom izvornih tekstova, uz upotrebu kvalitativnog analitičkog instumentarija, identifikuju potencijalne prednosti, ekonomske i socijalne, koje uspostavljanje konkurentskog poretka donosi, kao i utvrditi osnovne principe koje je neophodno slediti u izgradnji institucionalne strukture, a koji omogućavaju uspostavljanje tog poretka.

Hipoteza, koja će u radu biti testirana, jeste:

H: Konkurentski poredak, sa aspekta rezultata koji se u njemu postižu, generiše visok kvalitat ekonomskih performansi i vodi rešavanju značajnog dela socijalnih problema koji se pojavljuju u društvu.

Konkurentski poredak predstavlja superiornu alternativu u odnosu na druge (poznate) mehanizme alokacije resursa i dohotka. Ova činjenica proizilazi iz definicije STP, koji je dao A. Rüstow (1960, 51), a prema kojoj „Socijalno-tržišna privreda usmerava proizvodnju i raspodelu putem sistema slobodnih cena kroz konkurenciju između preduzeća, koja se, po pravilu, nalaze u režimu privatnog vlasništva, daleko produktivnije, svrsishodnije, pravičnije, jeftinije i pouzdanije" u odnosu na druge tržišne i netržišne privredne modele. U modelu STP obezbeđuje se efikasna alokacija resursa, ali i eliminacija siromaštva i izbegavanje pogrešne distribucije dohotka (Karsten, 1985). Izabrana tema je relevantna, ne samo sa aspekta rezultata koje je navedeni model u praksi generisao, već i iz razloga što je model STP bio oštro kritikovan i izazivao skepticizam u periodu kada je započela njegova implementacija, pogotovo od stranebritanskih ekonomista. Posmatrano iz današnje perspektive, ove kritike su se pokazale kao neutemeljene. Dodatni razlog atraktivnosti teme sastoji se $\mathrm{u}$ tesnoj vezi i bliskosti ideja u modelu STP i onih koje se pojavljuju u okviru novih teorijskih pravaca, poput institucionalne ekonomije, političke ekonomije ili konstitucionalne ekonomije (Vanberg, 1988), ili Poredak sa zatvorenim pristupom/Poredak sa otvorenim pristupom (LAO/ OAO) koncept, koji su razvili D. C. North, J. J. Wallis, S. B. Webb i B. R. Weingast (Zweynert, 2015). Osim toga, $\mathrm{u}$ različitim studijama $\mathrm{u}$ domenu ekonomske teorije, ali i u brojnim empirijskim istraživanjima utvrđena je veza između različitih elemenata modela STP i ekonomskih performansi. Posebno su značajna istraživanja koja su se bavila vezom između sloboda, posebno ekonomskih, i ekonomskog rasta (De Haan \& Sturm, 2000; Gwartney, Holcombe \& Lawson, 2004; Doucouliagos \& Ulubasoglu, 2006; Ivanović \& Stanišić, 2017). Rezultati ovih istraživanja dodatno potvrđuju značaj modela STP, jer se u njegovom središtu nalazi sloboda pojedinca - kao ishodište institucionalne strukture i kao nezamenljiv generator ekonomskog progresa.

Rad je strukturiran u šest sekcija. Nakon uvodnih razmatranja, sledeće tri sekcije su posvećene analizi specifičnog značaja koji konkurentski poredak ima sa aspekta rezultata koje generiše. Naime, u drugom delu je analiziran način na koji konkurentski poredak podstiče aktivnosti ekonomskih agenata ka produktivnom ponašanju, a što za rezultat ima efikasnu alokaciju resursa. Posebno interesantan je deo koji se bavi značajem konkurentskog poretka za obezbeđivanje (individualne) slobode ekonomskih aktera u najširem smislu reči, i time, posredno, utiče na efikasnost ekonomskog sistema u celini. Četvrta sekcija je posvećena potencijalnim socijalnim koristima do kojih konkurentski poredak dovodi. Kako je model STP baziran na jasnoj i čvrstoj institucionalnoj strukturi, u petom delu je analiza usmerena na identifikovanje pretpostavki neophodnih za ostvarenje takvog poretka. U zaključku će biti sumirani i dovedeni u međusobnu vezu rezultati istraživanja, sugerisana ograničenja, ali i identifikovani mogući pravci budućih istraživanja.

\section{KONKURENCIJA KAO PERPETUUM MOBILE EKONOMSKE EFIKASNOSTI}

Jedna od osnovnih pretpostavki u okviru modela STP jeste da jedino konkurentski poredak vodi efikasnim i održivim ekonomskim i socijalnim rezultatima. Posebno je značajna i neposredno uočljiva veza između konkurencije i ekonomske dinamike, odnosno, ekonomskog rasta, jer je odnos „konkurencije i rasta odnos uzroka i posledice" (Müller-Armack \& Erhard, 1972, 215). 
Konkurencija se posmatra kao stanje u konkretnom tržišnom segmentu, u kojem ne postoje ograničenja kako na strani ponude, tako ni na strani tražnje (Böhm, 1961). Veliki broj aktera na obe strane tržišta podrazumeva da odnosima razmene upravljaju i dominiraju odnosi kooperacije umesto subordinacije, što je od vitalnog značaja za efikasnu razmenu. U realnom privrednom životu je, ipak, od daleko veće važnosti broj učesnika na strani ponude u odnosu na broj učesnika na strani tražnje. To je posebno značajno sa aspekta devijacija koje mogu nastati u efikasnosti konkretnog tržišta.

U konkurentskom poretku, na najbolji način se rešava problem vezan za egoizam ekonomskih aktera, koji je, ujedno, glavna pokretačka snaga angažovanja u ekonomskom procesu. Naime, konkurencija ograničava destruktivno dejstvo egoizma, ali istovremeno i koristi njegov ogroman potencijal, usmeravajući angažovanje ekonomskih agenata ka najproduktivnijim aktivnostima, čime dovodi do najboljeg usklađivanja pojedinačnih i grupnih interesa (Böhm, 1942; Nawroth, 1961). Takvo usklađivanje pojedinačnih i kolektivnih interesa moguće je u konkurentskom poretku, pre svega, zbog toga što su ekonomski agenti, pojedinačno posmatrano, bez moći da utiču na odvijanje procesa razmene na tržištu. U takvim uslovima, egoizam i neposedovanje moći pojedinačnih aktera vodi ponašanju na tržištu koje karakteriše samovoljno poštovanje pravila, zabrana i uopšte pravila igre. Ujedno, to je i pretpostavka korisne i racionalno strukturirane interkacije i kooperacije. Kao posledica, toga smanjuju se i transakcioni troškovi, što dodatno stimuliše ekonomsku efikasnost.

Osnovni mehanizam putem kojeg konkurencija utiče na ekonomsku dinamiku jeste sistem cena. Samo u uslovima konkurentskog poretka cene će pravilno usmeravati ponašanje ekonomskih aktera. Cene su u konkurentskom poretku egzogeno određene (Eucken, 1952), tj. nalaze se van uticaja bilo kog pojedinačnog aktera. Ekonomske aktivnosti i planiranje poslovnih operacija odvija se na osnovu ove datosti. Cene su za sve učesnike na tržištu ex ante determinisane, i ne podležu promenama usled delovanja bilo koje državne ili privatne instance ili subjekta. Ukoliko bi cene zavisile od odluka državnih instanci, ili pojedinačnih odluka učesnika na tržištu, onda ne bi postojala niti sigurnost niti opravdana pretpostavka da bi takve cene bile prave. Kao takve, vodile bi, nesumnjivo, alokativnim neefikasnostima, koje bi bile posledica pogrešne osnove na kojoj bi ekonomski agenti formulisali poslovnu strategiju i donosili poslovne odluke. Nasuprot tome, snage konkurencije obezbeđuju da tržišne cene i troškovi proizvodnje budu adekvatno povezani, što utiče na to da poslovna kalkulacija ekonomskih agenata u najvećem (mogućem) stepenu bude egzaktna (Röpke, 1961). Pomenuti egzogeni karakter cena nikako ne znači i njihovu nepromenljivost tokom vremena. Naime, iako je jedan od bazičnih preduslova efikasnog ekonomskog sistema, u modelu STP monetarna stabilnost, odnosno, stabilnost cena, njihova promenljivost nikako ne ugrožava ovaj princip, jer pojedinačne cene mogu ići kako na dole, tako i na gore, dok opšti nivo cena ostaje stabilan. Osim toga, konkurentske cene su od suštinskog značaja za dugoročno usklađivanje sa troškovima, odnosno, one obezbeđuju da se cene pojedinačnih proizvoda, kratkoročno i dugoročno, usklađuju sa nivoom neophodnih troškova kokretnog dobra. Nesumnjiva prednost ovakvog režima pogotovo dolazi do izražaja u komparativnom kontekstu, tj. u odnosu na situacije koje karakteriše postojanje rente ili ekstraprofita, gde je reagibilnost cena, ali i ekonomska efikasnost, daleko niža.

Glavna snaga konkurencije u režimu fleksibilnih cena sastoji se u pružanju relevantnih informacija za ekonomske aktere. Slobodnom sistemu cena odgovara decentralizovano tržišno, odnosno, proizvodno upravljanje. To je, ujedno, najefikasniji način realizacije ukupnog proizvodnog potencijala. U uslovima konkurencije, zadovoljenje potreba ekonomskih aktera određenim dobrom, pri datom dohotku i raspoloživošću proizvodnih faktora, biće i najjefitinije (Lutz, 1962). Ne samo da konkurencija vodi najjeftinijoj i najvećoj mogućoj proizvodnji, već i čini ekonomske aktere stalno motivisanim na smanjivanje troškova. U realnom ekonomskom životu, dešava se konstantna diferencijacija potreba na strani tržanje, a konkurencija primorava ekonomske aktere na strani ponude na stalno prilagođavanje i u ovom domenu. 
Time se obezbeđuje, dodatno, adaptabilnost sistema. Konačni rezultat konkurentskih pritisaka nije samo smanjivanje troškova, već i dostizanje višeg nivoa kvaliteta proizvoda (Böhm, 1942).

Značajna snaga konkurencije u režimu slobodnih cena sastoji se i $\mathrm{u}$ tome što kreira stimulativnu strukturu podsticaja, čime se angažovanje, dakle, akcija i reakacija ekonomskih aktera usmeravaju ka najproduktivnijim ekonomskim aktivnostima. $\mathrm{Na}$ taj način se najefikasnije koordiniraju i regulišu komplikovane transakcije, a razmena postaje uređena i predvidiva. Poslovne kalkulacije ekonomskih agenata zavise od kvaliteta poslovnog odlučivanja, a u manjoj meri od eksternih faktora koji se nalaze van njihove kontrole. Stvaralačko angažovanje i preduzetnička inicijativa su u takvim okolnostima na najbolji način nagrađene (Eucken, 1947). Pošto u konkurentskom poretku ništa nije ex ante određeno, svi ekonomski agenti su maksimalno angažovani da zauzmu što bolju poziciju na tržištu. Time, konkurencija deluje na ekonomsku efikasnost, ne samo u statičkom, već i u dinamičkom smislu. Naime, sposobnosti, ideje, napori i talenti učesnika u ekonomskom procesu, na najefektniji način se stimulišu unutar konkurentskog poretka i nalaze se pod stalnom proverom (Stegmann, 1999).

Konkurencija obezbeđuje i najbolji okvir za adekvatno upravljanje i efikasnu upotrebu kapitala. $\mathrm{U}$ konkurentskom poretku, koji podrazumeva najveći stepen slobode za ekonomske agente i koji mora biti praćen proporcionalnom odgovornošću za odluke koje donose, opreznost prilikom investicionih aktivnosti će biti najveća. To je, ujedno, i pretpostavka boljem upravljanju kapitalom. Oprezan nastup na tržištu i izbegavanje pogrešnih odluka može se obezbediti samo ako te odluke prati i odgovornost. Drugim rečima, prema W. Eucken-u (1953, 20) „ko ostvaruje koristi (u poslovnim aktivnostima), mora snositi i (odgovornost za) štetu“. Kroz to se obezbeđuje adekvatna veza između odgovornosti i preduzetog rizika (Böhm, 1942), koja se nalazi u osnovi investicionih odluka. Ne manji značaj odgovornosti se sastoji u činjenici da je odgovornost konstrukcioni element poretka, u kojem vlada sloboda (Eucken, 1953). Stvaralačka moć poretka, baziranog na konkurenciji, proizilazi iz činjenice da je u njemu veliki broj pojedinca nezavisan, što omogućuje visok stepen samoodređenja. U takvim uslovima, pojedinci će biti podstaknuti da se produktivno angažuju, jer će imati punu slobodu, ali i odgovornost, da odlučuju o vrsti i načinu svog angažmana. Greške su u takvom sistemu skupe, a nagrade značajne.

Održavanje stabilnosti i ublažavanje konjunkturnih oscilacija je, takođe, jedna od posledica postojanja konkurentnog poretka. Naime, konkurencija primorava ekonomske aktere da stalno investiraju, ali i na ostale preduzetničke aktivnosti kojima obezbeđuje da njihove aktivnosti stalno budu usmerene na maksimalne moguće rezultate. Takvo ponašanje vodi neophodnim prilagođavanjima u sistemu, odnosno, obezbeđuje se neophodna reagibilnost sistema kao celine.

Odnos konkurencije i tehničkog progresa je ambivalentan. S jedne strane, tehnički progres vodi preuzimanju malih od strane većih preduzeća, usled čega dolazi do koncentracije na mnogim tržištima. S druge strane, on doprinosi, takođe, razvoju supstituta, širenju tržišta, i povećanoj sposobnosti prilagođavanja $u$ produkcionom procesu, ali i širenju tržišta rada. Time se povećava fleksibilnost i mobilnost faktora proizvodnje i proizvoda na mnogim tržištima (Eucken, 2001). Osim toga, konkurencija stimulativno deluje na tehnički progres, jer su ekonomski agenti primorani, usled konkurentskog pritiska, na kontinuirane inovacije shodno preferencijama kupaca, ali i da nastoje da ubrzaju implementaciju inovativnih rešenja (Symanski, 1999).

Izvesno je, takođe, da konkurencija izaziva i određene gubitke, pogotovo za one koji su u tržišnom nadmetanju slabiji. Međutim, na kraju i oni, kroz mnoge druge prednosti koje generiše konkurentski poredak, ostvaruju neto koristi od participacije u takvom procesu (Vanberg, 2002). Dakle, konkurencija ne samo da obezbeđuje adekvatan sistem nagrada za one koji su uspešni, već i pruža svojevrsnu kompenzaciju za one koji su manje uspešni. Na primer, efekat učenja i usmerenost ka inovacijama ne bi postojali kod pojedinih aktera, ukoliko se oni ne bi nalazili pod pritiskom konkurencije. Iako nijedan 
poredak nije savršen, pa tako ni konkurentski, ipak je naglašena njegova superiornost $u$ odnosu na alternativne tržišne strukture (Lutz, 1953). To se tiče, pre svega, efikasnosti funkcionisanja, kvaliteta i održivosti rezultata koji se u njemu postižu.

\section{SLOBODA KAO POLAZIŠTE I ISHODIŠTE KONKURENTSKOG PORETKA}

Samo u konkurentskom poretku može se očekivati da se on, shvaćen kao sistem pravila koji čini institucionalnu strukturu i sloboda, nalaze $u$ ravnoteži. U takvom poretku ne postoji moć koja bi ugrozila slobodu. Konkurentski poredak omogućuje svakom ekonomskom akteru da njegova sloboda ne bude ugrožena aktivnostima onih koji bi posedovali moć (Eucken, 1947). Drugi aspekt slobode, koji je obezbeđen konkurentskim poretkom, odnosi se na činjenicu da je pojedinac slobodan, da deluje u skladu sa sopstvenim interesima i shodno ličnoj proceni (Müller-Armack \& Erhard, 1972). To je, ujedno, određujući uslov efikasne razmene.

Polazište u relaciji između slobode i ekonomske efikasnosti u koncepciji STP jeste sloboda. Reverzibilnost odnosa se, u najmanju ruku, posmatra kao činjenica od drugorazednog značaja. Značaj je, dakle, u prednostima u pogledu blagostanja koje ona obezbeđuje (Böhm, 1961), a ne u uticaju blagostanja na slobodu. U tom smislu, najbolji način da se kreira ekonomska vrednost jeste u ostvarivanju slobode. Obezbeđivanje slobode kroz konkurenciju znači "obezbeđivanje rasta" (Müller-Armack \& Erhard, 1972). Iako je sloboda koju obezbeđuje konkurentski poredak, pre svega, nematerijalna vrednost (Böhm, 1942), ipak je njeno obezbeđivanje odlučujuće u rastu ekonomske efikasnosti.

Sloboda, koja je neraskidivo vezana za postojanje konkurentskog poretka, je glavni argument za superiornost ovog poretka u odnosu na alternativne forme organizacije privrednog života. U uslovima slobodnih i stabilnih cena, konkurentski poredak obezbeđuje slobodu planiranja svim ekonomskim akterima. Ekonomski akteri, u takvim uslovima, nisu zavisni od treće strane koja određuje (neefikasne) cene - države ili određene monopolske strukture. Kako su ekonomski agenti slobodni da planiraju svoje aktivnosti, ali i snose odgovornost za njih, koja je poduprta tržišnim i institucionalnim sankcijama, za očekivati je da narušavanje pravila poretka bude minimalno. Neposredna posledica toga je minimiziranje transakcionih troškova, povećanje obima i broja transakcija, i produbljivanje poslovnih odnosa među ekonomskim agentima.

Konkurentski poredak obezbeđuje najviši stepen slobode izbora kako za potrošače, tako i za proizvođače. Kako konkurencija pospešuje odnose razmene, time ona doprinosi i mirnom rešavanju sporova na tržištu. Ovaj aspekt se usko oslanja na sistem cena. Naime, sistem cena u konkurenciji podrazumeva da svako slobodno odlučuje kako da upotrebi resurse kojima raspolaže. Odluke se ne nalaze pod uticajem treće strane - države ili poslovnog partnera sa monopolskom pozicijom, čime je orijentacija na cene $u$ potpunosti bazirana na slobodi odlučivanja (Böhm, 1950). Iako je koordinacija, a ne subordinacija $\mathrm{u}$ konkurentskom poretku ta koja usmerava ekonomske odnose i iako se u centru ovakvih odnosa nalazi sloboda pojedinačnih aktera, sloboda nije apsolutna. Ipak se ekonomski subjekti nalaze pred ograničenim brojem mogućnosti izbora i mogućnosti ponašanja. Osim toga, ekonomski akteri nisu apsolutno slobodni, jer njihovo delovanje zavisi od ponašanja drugih aktera. Oni moraju uzeti u obzir postojanje drugih ekonomskih aktera, njihove interese i ponašanja. Shodno tome, sloboda je ograničena. Ona je daleko više od slobode koja ekonomskim akterima stoji na raspolaganju $u$ alternatvnim tržišnim strukturama. To se posebno odnosi na situaciju gde su ekonomski akteri izloženi naredbama i drugim ograničenjima, koja slobodu sužavaju. Dakle, sloboda ne podrazumeva slobodu od (bilo kakvih) ograničenja, koja su uslov uređenih transakcija, ili slobodu od pravila trajnijeg karaktera i dobrih (poslovnih) običaja.

Konkurencija nije samo preduslov najšire i opšte shvaćene slobode pojedinca, već i pretpostavka za to, da se neka prava, koja predstavljaju garanciju 
slobode, ne „iskrive“ i preobraze u sredstvo moći. Ovo se, posebno, odnosi na slobodu ugovaranja. Iako je sloboda ugovaranja od esencijalnog značaja za ekonomsku efikasnost, ipak je konkurentski poredak nezamenljiv za očuvanje suštine i prirode ove slobode. Razlog za to je što se sama priroda slobode ugovaranja zasniva, upravo, na ekonomskom i tržišnom poretku baziranom na konkurenciji. Konkurencija onemogućava da se sloboda ugovaranja zloupotrebi za sužavanje slobode strana u ugovornim odnosima (Eucken, 1953). Dakle, princip slobode ne sme podrazumevati zloupotrebu slobode sa ciljem njenog sužavanja kod strana $\mathrm{u}$ transakciji. Upravo iz tog razloga značenje slobode ugovaranja daleko nadilazi (usko) formalno-pravno vrednovanje njenog sadržaja.

Iako je konkurentski poredak povezan najneposrednije sa pojedinačnim aspektima slobode, poput slobode ugovaranja, efikasnost ekonomskog sistema $\mathrm{u}$ dugom roku je određena stepenom ostvarenja sloboda u najširem smislu, odnosno, u svim segmentima i aspektima. To proizilazi na osnovu činjenice da postoji tesna međusobna povezanost između različitih domena slobode. Ostvarivanje jednog aspekta zahteva, istovremeno, i postojanje drugog aspekta. Na primer, sloboda preduzetničkog angažovanja je preduslov slobode izbora potrošača (Müller-Armack \& Erhard, 1972).

Konkurencija je preduslov funkcionalnosti privatnog prava iz razloga što pravne relacije podrazumevaju regulisanje odnosa, ovlašćenja i razmene između jednakih strana u transakciji, odnosno, lica koja u odnosu jednih naspram drugih ne poseduju političku moć ili socijalne privilegije (Böhm, 1966). Konkurencija deluje i preventivno na uspostavljanje političke moći. Kao takva, ona je kompatibilna kako sa demokratijom, tako i sa na njoj zasnovanom pravnom poretku. Oslanjanjem na tržišne snage, obezbeđivanjem funkcionalnosti pravnog poretka i ograničavanjem državnog intervencionizma koji bi imao posledice po ograničavanje slobode (Böhm, 1961), konkurentski poredak obezbeđuje najviši stepen ekonomske efikasnosti. Ograničavanjem državne intervencije konkurencija čuva autonomiju ekonomskih aktera, a time i alokaciju kako proizvodnih resursa, tako i donošenje potrošačkih odluka. Iz tog razloga, konkurentski poredak, po svojoj prirodi, predstavlja demokratski mehanizam.

\section{SOCIJALNE KORISTI U KONKURENTSKOM PORETKU}

Iako se konkurentski poredak smatra najefikasnijim od svih alternativnih, značajno je pitanje - do kakvih posledice on dovodi u socijalnom kontekstu? Socijalne koristi konkurentskog poretka imaju posebnu važnost u okolnostima kada se ekonomski sistem suočava sa teškoćama. U tim uslovima, posebno dolazi do izražaja da ono što doprinosi rastu produktivnosti, mnogo više ima socijalnu nego ekonomsku vrednost (Stegmann, 1999). Socijalnu vrednost konkurentskog poretka treba posmatrati, prvenstveno, u ovom kontekstu. Tržište ne može da dovede do poželjnih socijalnih ishoda ukoliko konkurentski poredak ne funkcioniše adekvatno. Dakle, konkurentski poredak je per se preduslov rešenja značajnog dela problema koji se pojavljuju u socijalnoj sferi. S druge strane, konkurencija je ključ rešavanja socijalnih problema iz razloga što nije moguće pronaći univerzalni (materijalni) pokazatelj pravičnosti. Svako (naglašenije) odstupanje $u$ raspodeli od onog koje se ostvaruje putem konkurentskog mehanizma dovelo bi do distorzija, kako u ekonomskoj, tako i u socijalnoj sferi. Kod svake vrste raspodele se pojavljuje opasnost da će raspodela biti pod uticajem snaga koje će samu raspodelu udaljiti od principa da svakom pripada po njegovom učinku, a koji teži da se u konkurentskom poretku automatski ostvari (Lutz, 1953).

U uslovima konkurencije se dugoročno obezbeđuje najveća i najraznovrsnija proizvodnja, koja ne isključuje učešće bilo kojeg pojedinca. Učešće $u$ ukupnom ekonomskom uspehu nacionalne ekonomije se realizuje kroz bolju dostupnost i kvalitetnija javna dobra i usluge, radne šanse ili rastuće plate. Konkurentski poredak kreira okvir u kojem se materijalna osnova društva razvija na način da se takvim razvojem, u velikoj meri, mogu rešiti postojeći 
socijalni problemi. Kroz obezbeđivanje velikog broja mogućnosti različitim pojedincima, nezavisno od njihove socijalne pozadine, doprinosi se i većoj pokretljivosti i socijalnoj koheziji. Kako postojanje konkurentskog poretka podrazumeva i odsustvo moći, njegovo iskorišćavanje od strane pojedinaca u velikoj meri je onemogućeno. Konkurentski poredak omogućava da se socijalni problemi rešavaju u duhu slobode, čime je i garant njenog postojanja (Eucken, 1953 , 24). On primorava ekonomske aktere na brzo reagovanje, bilo da je reč o rešavanju problema ili korišćenju poslovnih šansi. I ovo se može posmatrati kao svojevrsna (ekonomska) prednost koja ima socijalni karakter, jer ",ko brzo reaguje, pomaže duplo“ (Müller-Armack \& Erhard, 1972, 280).

Pošto konkurentski poredak počiva na koordinacionom, a ne subordinacionom principu (Lutz, 1971), veze i odnosi razmene između ekonomskih aktera se odvijaju slobodno, što podrazumeva relaksaciju socijalnih odnosa i ublažavanje konflikata. Koordinacija razmene u uslovima konkurencije omogućava kontinuirano prilagođavanje između pojedinačnih i preduzetničkih planova. U tom pogledu, koordinacija predstavlja mehanizam uređenja međuljudskih odnosa $u$ sferi razmene i proizvodnje. Amortizacija socijalnih konflikata u konkurentskom poretku proizilazi i iz toga što takva struktura doprinosi rastu plata najšireg sloja stanovništva (Müller-Armack, 1962). Iako viši nivo dohotka predstavlja objašnjenje mehanizma motivacije kod ekonomskih agenata, a time i ekonomske efikasnosti uopšte, njegov značaj se sastoji i u tome što on, istovremeno, doprinosi boljem socijalnom vrednovanju pojedinca koji ga ostvaruju. Naime, viši nivo dohotka je potvrda radnog napora pojedinca (Symanski, 1999), čime konkurencija, dodatno, pozitivno utiče na oblikovanje relacija u socijalnom domenu.

Konkurentski poredak se zasniva na ideji pravičnosti, koja proizilazi iz činjenice da ekonomski agenti ne poseduju moć. Naime, u takvom poretku, svako je nagrađen shodno svom doprinosu. Ukoliko se ravnoteža moći promeni, $u$ smislu da postoji značajna asimetrija moći $u$ sistemu, sistem relativnih cena i kvalitet funkcionisanja ekonomskog sistema teži da bude narušen. Ne samo da cene $u$ jednom takvom sistemu nisu dobra osnova za poslovnu kalkulaciju, već je i sama ideja o pravičnosti narušena karakterom odluka onih koji moć poseduju. U tom smislu, cene u sistemu konkurencije, motivisanjem ekonomskih aktera na kontinuirane napore i prilagođavanje, sprečavaju uspostavljanje okoštalih institucionalnih struktura. Time se podstiče samoodgovornost svih ekonomskih aktera, čime se podupiru napori ka kontinuiranoj efikasnosti ekonomskog procesa. To je, ujedno, i objašnjenje zašto se princip konkurencije smatra korenom ekonomskog, socijalnog i društvenog napretka, jer on ima podjednaku važnost i podjednako tangira sve članove društva, od preduzetnika do svih drugih profesija. Cene u konkurentskom sistemu odražavaju nužnost, pravičnost i racionalnost (Böhm, 1947), čime su nezamenljiv element kako ekonomske efikasnosti, tako i preduslov pravičnosti u sistemu. Cene koje se formiraju na tržištu, u uslovima konkurencije, ne mogu biti zloupotrebljene od bilo kog učesnika u ekonomskom procesu. Ne postoji pojedinačna volja koja ih određuje, ali ni određena (svesna) kolektivna volja koja propisuje kako i na kom nivou one treba da se nalaze. Međutim, one imaju prinudno dejstvo time što se njih svi učesnici u ekonomskom procesu moraju pridržavati. Ovo dejstvo je rezultat mnogobrojnih, jednakih, slobodnih i spontanih reakcija koje se nalaze u osnovi procesa razmene. Usled navedene specifičnosti u formiranju, konkurentske cene nemaju uticaj na političke, socijalne i ekonomske slobode.

Kako konkurentski poredak označava stanje odsustva ograničenja za učestvovanje u konkretnom ekonomskom procesu, time svi koji učestvuju, ili nastoje da učestvuju, u ekonomskom procesu imaju podjednake šanse za uspeh. Samo pod ovim pretpostavkama, odnosno, pri odsustvu ograničenja ulaska i izlaska sa tržišta, moguće je očekivati sve prednosti i dugoročno etabliranje konkurentskih struktura (Kersting, 2010).

Značajan uticaj konkurencije u socijalnoj sferi odnosi se na smanjenje troškova. Naime, dugoročno je svaki ekonomski agent prinuđen da svoje troškove minimizira. Posledično, dolazi do pojeftinjenja proizvoda. Kada dođe do smanjenja troškova u širem 
obimu, dolazi i do smanjenja cena u odgovarajućem rasponu. Dakle, prednosti od smanjenja troškova ne ostaju samo kod proizvođača, već jedan deo dolazi i do potrošača. Putem toga, dolazi do socijalizacije ekonomskog progresa bez upotrebe pravne prinude.

Iako konkurentski poredak, kroz njemu inherentan automatizam sistema slobodnih cena, generiše mnoge socijalne i ekonomske prednosti, njegovo ostvarivanje zahteva političku i ideološku potporu. One treba da obezbede dugoročnu klimu, kojom se štiti i promoviše takav poredak (Böhm, 1961). Vera ekonomskih agenata u sebe i sopstvenu moć u kontinuirano promenljivom okruženju zauzima centralno mesto $u$ razumevanju socijalnog značaja konkurencije. Jedna od posledica takvog okruženja, u sadejstvu sa snagom konkurencije, jeste i mobilnost ekonomskih aktera i kontinuirana potraga za njihovim najproduktivnijim angažmanom. Ništa manje nije bitna ni pozicija pojedinaca prema monopolima i drugim alternativama konkurentskom poretku (Böhm, 1942). To je značajno iz razloga što stavovi i preferencije pojedinaca determinišu prostor u kome se stvara (formalna) institucionalna struktura i odvija, uopšte, celokupni politički proces.

\section{INSTITUCIONALNE PRETPOSTAVKE ZA RAZVOJ KOKURENTSKOG PORETKA}

U osnovi, u okviru koncepta STP mogu se izdvojiti tri fundamentalna preduslova koji uslovljavaju mogućnost funkcionisanja privrede na principima koji karakterišu konkurentski poredak, a time i ostvarivanje prednosti koje taj poredak donosi.

Prva pretpostavka odnosi se na zahtev za postojanje otvorene ekonomije. Model konkurentskog poretka nije zamisliv bez postojanja otvorenog tržišta. Najviši stepen otvorenosti tržišta je imperativ, koji je od strane države inkorporiran u svim domenima ekonomske politike (Eucken, 1952). Izuzetak od ovog zahteva bi se mogao odnositi na situacije kada su inostrani konkurenti subvencionisani od strane države i kao takvi čine nelojalnu konkurenciju. Značaj spoljne trgovine ne ogleda se samo u konkurentskim pritiscima na domaće ekonomske aktere, već proizilazi i iz činjenice da konkurentski poredak ne može biti $u$ potpunosti razvijen bez adekvatnog uključivanja u međunarodnu podelu rada. Samo u tim uslovima, fundamentalni podsticaji koje konkurencija obezbeđuje biće dugoročno prisutni u sistemu. Dakle, ne samo pritisak konkurencije na unutrašnjem tržištu, već i nastup na inostranom tržištu obezbeđuju nezamenljive podsticaje za domaće ekonomske subjekte.

Pritisak koji nastaje kao posledica konkurencije prevazilazi neposredni uticaj na ekonomske aktere koji se nalaze u odnosima konkurencije. On snažno deluje i na odnose na celokupnom tržištu. Na primer, dobavljači će biti pod snažnim uticajem da inoviraju i snižavaju troškove kako bi zadržali ugovore, iako se ne nalaze u neposrednom odnosu konkurencije. Osim toga, stepen u kojem postoji otvorenost tržišta može biti značajan faktor stabilnosti opšteg nivoa cena $\mathrm{u}$ nacionalnoj ekonomiji. U tom smislu, konkurentski poredak baziran na slobodnom režimu cena ne može se zamisliti bez otvorenosti tržišta.

Sužavanje (konkretnog) tržišta putem politike zaštite u domenu spoljne trgovine ima za posledicu ne samo uticaj na tržišni segment koji se nalazi pod takvim merama, već i značajno šire posledice. Ekonomski akteri na drugim tržištima mogu (potpuno opravdano) tražiti zaštitu. Preduzeća koja se nalaze niže u lancu prozvodnje mogu biti podstaknuta na ponašanje koje bi vodilo većem stepenu koncentracije, a što bi omogućilo veću moć uticaja na mere ekonomske politike kojima bi i oni ostvarili određene privilegije. Dakle, dolazi do narušavanja veza između pojedinačnih tržišta, pošto smanjivanje jednog tržišta automatski vodi smanjivanju i drugih tržišta (Eucken, 1952). Sama zaštita predstavlja značajan preduslov da dođe do stvaranja asimetričnih pozicija moći na tržištu. Osim toga, domaće tržište bi moglo biti u takvim uslovima neatraktivno za ulaganje, što bi moglo ograničiti transfer tehnologije. U slučaju narušavanja veza između pojedinačnih tržišta, tržišni sistem u celini ne može efikasno funkcionisati. Osim toga, zatvaranje tržišta protivreči jednom od osnovnih načela u konceptu STP, tj. međuzavisnosti poredaka (Interdependez der Ordnungen). U takvim uslovima dolazi do poremećaja u alokaciji. Ukoliko je deo 
tržišta koji se štiti značajan deo ukupnog ekonomskog sistema, uticaji na ostale poretke mogu biti posebno snažni, poput pravnog ili političkog (Eucken, 2001). Reč je, zapravo, o neefikasnostima uzrokovanih pojavom rent-seeking ponašanja, odnosno, uticajem interesnih grupa, kada su institucije političkog i pravnog sistema oblikovane shodno interesima određenih grupa, a ne vođene efikasnošću ekonomskog sistema u celini.

Druga pretpostavka jeste privatna svojina, koja pripada bazičnim preduslovima uspešnog ekonomskog sistema (Müller-Armack \& Erhard, 1972). Naime, privatna svojina predstavlja strukturno pravo i fundamentalni faktor efikasnosti celokupnog poretka (Nawroth, 1961). Iz same te činjenice nedvosmislena je kompatibilnost između privatne svojine i konkurentskog poretka. Međutim, i uticaj koji ide od konkurencije na privatnu svojinu je od velikog značaja. Naime, konkurentski poredak je jedini koji obezbeđuje (najveću) društvenu vrednost privatne svojine $i$ uslove $u$ kojima dolazi do njene legitimizacije (Rüstow, 1960). Konkurencija je nezamenljiv mehanizam kontrole privatne svojine (Eucken, 1953). Samo postojanje konkurentskog poretka podrazumeva i visok stepen disperzije vlasništa u ekonomiji (Böhm, 1942).

Privatna svojina je ne samo preduslov konstituisanja konkurentskog poretka, već i preduslov povećanja slobode pojedinca. Privatna svojina je instrument garancije individualne slobode, i to dvojako. Pre svega, privatna svojina štiti pojedince, time što predstavlja garanciju nezavisnosti individualnih odluka i odgovornosti u odnosu na druge aktere $u$ ekonomskom procesu. Takođe, ona predstavlja garant zaštite pojedinaca od države i njenog monopola sile. Kroz ove dve funkcije se posmatra uloga privatne svojine kao esencijalnog uslova slobode (Röpke, 1957). Suprotno, u odsustvu konkurentskog poretka, privatna svojina (sa visokim stepenom izvesnosti) postaje instrument ograničavanja slobode, stvaranja renti i, generalno, dovodi do poremećaja u ekonomskom procesu i značajnih socijalnih troškova (Eucken, 1952). Dakle, konkurentski poredak omogućava efikasno korišćenje privatne svojine i onemogućava njenu zloupotrebu. Esencijalni značaj privatne svojine ogleda se $\mathrm{u}$ većoj predvidivosti, koja je od značaja za strane u transakcijama, ali i u sigurnosti koju ona predstavlja za titulare. U tom smislu, ulazak u poslovne transakcije će biti olakšan ukoliko poslovni partner poseduje imovinu, koja za drugu stranu znači i odsustvo uticaja treće strane koja nije neposredno uključena $u$ transakciju, na primer finansijskog posrednika. Isto tako, poslovne aktivnosti koje su pokrivene imovinom obezbeđuju veći stepen sigurnosti titularima, time što je obezbeđena veća reagibilnost na promenu tržišnih uslova. Takva vrsta reagibilnosti može biti u značajnoj meri sužena, ukoliko su poslovne aktivnosti finansirane putem ugovora o pozajmici. Vlasništvo je pretpostavka ne samo slobode, nego i odgovornosti u delovanju, jer ukoliko ekonomski akteri svojinom garantuju za svoje odluke, onda će ona predstavljati i značajan instrument usmeravanja ekonomskih aktivnosti (Lutz, 1962).

Treća pretpostavka odnosi se na vladavinu prava, koja je garant i mehanizam zaštite konkurentskog poretka, a time i ekonomske efikasnosti i rasta produktivnosti (Stegmann, 1999). Samo država, koja je bazirana na vladavini prava, je garant konkurentskog poretka (Erhard, 1961), obezbeđujući jednakost pred zakonom za sve učesnike u tržišnoj utakmici. Iz tog razloga, način konstituisanja pravnog poretka ima odlučujući značaj u izgradnji institucionalne strukture (Lutz, 1971). Takođe, ovde se pojavljuje i obrnuti kauzalitet: sposobnost i efikasnost države je određena prisustvom konkurentskog poretka (Nawroth, 1961). Kroz državu se reflektuje, na najneposredniji način, princip međuzavisnosti poredaka u društvu.

U modelu STP, vladavina prava, koju karakteriše postojanje pravne države, podrazumeva dvostruku zaštitu ekonomskih aktera. Vladavina prava obezbeđuje zaštitu pojedinca od države, odnosno, organa prinude. Iz tog razloga, potrebno je da državna struktura i njeni elementi budu kontrolisani kroz pravni poredak, odnosno, zakone. To se postiže kreiranjem institucionalne strukture koja jasno specificira procedure i načine državne intervencije, vodeći računa o tome da se sačuva maksimalni stepen slobode i zaštite pojedinca, što, svakako, isključuje arbitrarnost i ad hoc postupanje državnih organa. Mnogi od ovih aspekta su normativno uređeni 
ustavom, a operativno rešenjima u okviru upravnog prava. Drugi nivo zaštite, koji podrazumeva postojanje pravne države, odnosi se na zaštitu koju pravni poredak obezbeđuje pojedincima $u$ odnosu na druge aktere $u$ procesu razmene. Ovaj aspekt dobija na značaju u situacijama asimetričnih odnosa moći, (Eucken, 2001). Mogućnost narušavanja odnosa razmene je dvojaka. S jedne strane, onaj ko ima moć u stanju je da neposredno određuje odnose razmene. $S$ druge strane, može biti u mogućnosti da izvrši uticaj na kreiranje pravila u političkom procesu. Samo u situaciji kada postoji simetrija moći, pojedinac je prinuđen da kroz vođenje računa o interesima (svih) strana $\mathrm{u}$ transakciji dođe do realizacije cilja (Nawroth, 1961). U ovakvoj situaciji, garantuje se maksimalna sloboda svakog pojedinca. Pritom, čvrstina i impersonalnost jeste odlika dobrih pravila kojima se sloboda pojedinca u sistemu čuva (Böhm, 1942). Osim toga, vladavina prava obezbeđuje i zaštitu u odnosu na interesne grupe. Dakle, pravna država je garant slobode i njen zadatak je da političku i/ili ekonomsku moć pojedinca ili grupa kontroliše putem zakona (Gutmann, 1991). Štiteći slobodu pojedinca od (zloupotrebe) države i od zloupotrebe slobode onih koji poseduju moć, ali i od uticaja interesnih grupa, stvaraju se uslovi za nastanak i opstanak konkurentskog poretka. U sistemu u kome dolazi do zloupotrebe moći od strane pojedinca $\mathrm{i} / \mathrm{ili}$ interesnih grupa, kao i neregulisane intervencije države, konkurentski poredak ne može nastati, a ukoliko postoji, ne može opstati (Müller-Armack \& Erhard, 1972).

\section{ZAKLJUČAK}

Jedna od osnovnih pretpostavki u okviru modela STP jeste da konkurentski poredak vodi efikasnim i održivim ekonomskim i socijalnim rezultatima. On to čini bolje u odnosu na (druge) dostupne alternative, usmeravajući angažovanje ekonomskih agenata ka najproduktivnijim aktivnostima, ali i smanjujući transakcione troškove putem omogućavanja uzajamno korisne i racionalno strukturirane interakcije i kooperacije među ekonomskim agentima. Snage konkurencije obezbeđuju da cene i troškovi budu adekvatno povezani, što utiče na to da poslovna kalkulacija ekonomskih agenata u najvećem stepenu bude egzaktna. Konkurencija ne samo da vodi najjeftinijoj i najvećoj mogućoj proizvodnji, već i čini ekonomske aktere stalno motivisanim na smanjivanje troškova. Osim prilagođavanja u domenu troškova, konkurencija čini nužnim i prilagođavanje konstantnoj diferencijaciji potreba na strani tržanje, a posledično i višem kvalitetu proizvoda, što podupire adaptabilnost ekonomije. Rezultat je inovativna ekonomija i sistem kojeg karakterišu kontinuirane promene i sposobnost njihove brze implementacije.

U osnovi aktivnosti koje preduzimaju ekonomski agenti nalazi se sloboda, ali ona u modelu STP ima vrednost samo ukoliko je praćena i odgovornošću. Sloboda obezbeđuje rezultate, samo ukoliko ekonomski agenti snose i odgovornost. Stvaralačka moć poretka, baziranog na konkurenciji, proizilazi iz činjenice da $\mathrm{u}$ takvom poretku veliki broj pojedinca jeste nezavisan, što omogućuje visok stepen samoodređenja i, shodno tome, stalnog traganja za produktivnim angažovanjem.

Konkurentski poredak ne samo da obezbeđuje slobodu i podstiče produktivno ponašanje ekonomskih aktera, već ima i značajne socijalne implikacije. Shodno osnovnim postulatima u okviru modela STP, sve što doprinosi rastu produktivnosti ima veliki socijalni značaj. Ovaj aspekt je od posebnog značaja za periode kriza. Osim toga, konkurentski poredak obezbeđuje i generalno prihvatljivo stanje u raspodeli. Socijalna superiornost konkurentskog poretka ogleda se i kroz čitav niz drugih rezultata kojima on vodi, od najveće i najraznovrsnije proizvodnje, do bolje dostupnosti i kvalitetnijih javnih dobara i usluga, boljih i brojnijih radnih šansi, kao i rastućih plata najšireg sloja stanovništva. Time što je u takvom poretku akcenat na rezultatima, koji se u njemu kontinuirano preispituju, pa su moguća i napredovanja i nazadovanja, konkurenstki poredak dovodi do veće socijalne pokretljivosti. Sistem koji obezbeđuje svima iste šanse podrazumeva i daleko viši stepen socijalne kohezije, odnosno, prihvatljivosti za najširu populaciju. To su, ujedno, i neki od najznačajnijih rezultata do kojih se došlo ovim istraživanjem, a koji potvrđuju pretpostavku o značaju, ekonomskom i socijalnom, koji ima postojanje konkurentskog ekonomskog poretka. 
Dostizanje efikasnih socijalnih i ekonomskih ishoda $\mathrm{u}$ modelu STP podrazumeva postojanje institucionalnog okruženja u kojem su takvi rezultati mogući. U tom smislu, imperativ je da postoji najviši stepen otvorenosti tržišta, a što kao princip mora biti inkorporirano u svim domenima ekonomske politike. Konkurentski poredak je nezamisliv bez jasno definisanih vlasničkih prava. On počiva de facto na režimu privatne svojine. Njen značaj se sastoji, prevashodno, u snažnim podsticajima aktivnostima na očuvanju i uvećanju vrednosti resursa, ali i na obezbeđivanju veće sigurnosti i predvidivosti za strane $\mathrm{u}$ transakcijama. Privatna svojina obezbeđuje najveći mogući stepen motivacije kada je u pitanju efikasna alokacija resursa, kao i izvesnost i najmanji stepen ograničenja kada je u pitanju njena upotreba i stupanje u poslovne transakcije. Međutim, ukoliko institucionalna struktura ne štiti konsekventno ono što konkurentski poredak podrazumeva, a to su sloboda i odgovornost ekonomskih aktera prilikom razmene, posledično dolazi do devijacija $\mathrm{u}$ razmeni, a efikasnost će biti narušena. U uslovima slabe institucionalne strukture, pojedinci ili grupe koje imaju ekonomsku moć nastojaće da socijalizuju gubitke i/ili ostvare dobitke zahvaljujući tržišnoj poziciji, a ne konkurentnosti proizvoda ili usuge koju nude. Iz tog razloga, kao krucijalni preduslov jeste postojanje vladavine prava, jer konkurentski poredak nastaje i opstaje samo uz pomoć državnog angažovanja, odnosno, zaštitom koju obezbeđuju zakoni čija stvaralačka snaga zavisi od snage pravne države. Vladavina prava obezbeđuje jednakost pred zakonom za sve ekonomske aktere, onemogućavajući privilegovan položaj bilo kome, sprečavajući ostvarivanje renti ili socijalizaciju gubitaka usled pogrešnih poslovnih odluka.

Mogućnosti daljeg istraživanja su višestruke. Jedna se tiče mogućnosti daljeg istraživanja konstitutivnih pricipa modela STP i veza između njih i konkurentskog poretka. Posebno interesantno istraživanje bi se ticalo vladavine prava. Osim toga, kako konkurentski poredak ne vodi uvek samo efikasnim ishodima, model STP predviđa oblikovanje institucionalnog okvira, takođe, shodno regulativnim principima, kojima bi se otklonile ili ublažile distorzije do kojih dovodi sistem baziran na slobodnom tržištu. Značaj, sadržaj i implikacije ovih principa predstavljaju potencijalno interesantno polje istraživanja. Osim toga, $\mathrm{u}$ ovom domenu bila bi posebno interesantna analiza slučajeva koji podrazumevaju odstupanje od konkurentskih tržišnih struktura i iznalaženje načina za preventivno delovanje protiv uspostavljanja asimetričnih odnosa na tržištu. S druge strane, empirijska analiza i verifikacija pojedinačnih aspekata STP u kontekstu funkcionisanja savremenih privreda mogla bi predstavljati dodatni pravac budućih istraživanja. Posebno interesantna bi bila analiza sličnosti koje postoje između institucionalne ekonomije i STP. Dodatni razlog tome može biti i činjenica da su predstavnici STP bili kritičari klasične ekonomske teorije, dok su institucionalisti, jednim značajnim delom, kritikovali neka ograničenja neoklasične ekonomske teorije. Budući pravci istraživanja predstavljaju ujedno, i najbitnija ograničenja ovog rada - oslanjanje isključivo na teorijsku analizu, odsustvo povezanosti teorijskih pretpostavki i principa sa realno ostvarenim stepenom njihove operacionalizacije $\mathrm{u}$ funkcionisanju privrede SR Nemačke, kao i, eventualno, empirijska valorizacija pomenutog modela $\mathrm{u}$ komparativnom kontekstu.

\section{REFERENCE}

Berger, H. (2006). Optimal central bank design: Benchmarks for the ECB. The Review of International Organizations, 1(3), 207-235. doi:10.1007/s11558-006-8344-8

Böhm, F. (1942). Die Gesellschaftskrisis der Gegenwart. ErlenbachZürich, Switzerland: Eugen Rentsch Verlag.

Böhm, F. (1947). Kartelauflösung und konzernentflechtung. Spezialistenaufgabe oder schicksalsfrage? In T. Roser, \& W. Oswalt (Hrsg.). Entmachtung durch Wettbewerb, 2007, (pp. 59-91). Münster, Bundesrepublik Deutschland: LIT Verlag.

Böhm, F. (1950). Wirtschaftsordnung und Staatsverfassung. Tübingen, Bundesrepublik Deutschland: Verlag J. C. B. Mohr.

Böhm, F. (1961). Demokratie und Ökonomische Macht. (Sonderdruck) Karlsruhe, Bundesrepublik Deutschland: Müller Verlag. 
Böhm, F. (1966). Privatrechtgesellschaft und Marktwirtschaft. ORDO - Jahrbuch für die Ordnung von der Gesellschaft und Wirtschaft, 17, 75-151.

De Haan, J., \& Sturm, J. E. (2000). On the relationship between economic freedom and economic growth. European Journal of Political Economy, 16(2), 215-241. doi.org/10.1016/S01762680(99)00065-8

Doucouliagos, C., \& Ulubasoglu, M. A. (2006). Economic freedom and economic growth: Does specification make a difference? European Journal of Political Economy, 22(1), 60-81. doi.org/10.1016/j.ejpoleco.2005.06.003

Erhard, L. (1961). Deutsche Wirtschaftspolitik - Der Weg der Sozialen Marktwirtschaft. Düsseldorf, Bundesrepublik Deutschland: Econ-Knap.

Eucken, W. (1947). Über die zweifache wirtschaftspolitische Aufgabe der Natinalökonomie. In N. Goldschmidt, \& M. Wohlgemuth (Hrsg.). Grundtexte zur Freiburger Tradition der Ordnungsökonomik, 2008, (pp. 133-155). Tübingen, Bundesrepublik Deutschland: Mohr Siebeck.

Eucken, W. (1952). Grundsätze der Wirtschaftspolitik. Tübingen, Bundesrepublik Deutschland: J. C. B. Mohr.

Eucken, W. (1953). Wettbewerb, Monopol und Unternehmer. Bad Nauheim, Bundesrepublik Deutschland: Vita Verlag.

Eucken, W. (2001). Wirtschaftsmacht und Wirtschaftsordnung Londoner Vorträge zur Wirtschaftspolitik und zwei Beiträge zur Antimonopolpolitik. Münster, Bundesrepublik Deutschland: LIT Verlag.

Gutmann, G. (1991). The intellectual basis and historical development of social market economy. In W. Jung (Ed.). Social market economy: An economic system for developing countries (pp. 13-52). Sankt Augustin, Bundesrepublik Deutschland: Academia Verlag Richarz.

Gwartney, J. D., Holcombe, R. G., \& Lawson, R. A. (2004). Economic freedom, institutional quality, and cross-country differences in income and growth. Cato Journal, 24(3), 205233.

Hielscher, K., \& Markwardt, G. (2012). The role of political institutions for the effectiveness of central bank independence. European Journal of Political Economy, 28(3), 286-301. doi:10.1016/j.ejpoleco.2011.08.004
Hillebrand, R. (2015). Germany and its Eurozone crisis policy: The Impact of the country's ordoliberal heritage. German Politics and Society, 33(1), 6-24. doi.org/10.3167/ gps.2015.330102

Ivanović, V., \& Stanišić, N. (2017). Monetary freedom and economic growth in new European Union member states. Economic research, 30(1), 453-463. doi:10.1080/133167 7X.2017.1305803

John, K. D. (2007). The German social market economy - (Still) a model for the European Union? Theoretical and Applied Economics, 3(508), 3-10.

Karsten, S. G. (1985). Eucken's 'social market economy' and its test in Post-War West Germany: The economist as social philosopher developed ideas that parallelled progressive thought in America. American Journal of Economics and Sociology, 44(2), 169-183. doi.org/10.1111/j.1536-7150.1985. tb02331.x

Kersting, W. (2010). Marktwirtschaft, staat und soziale gerechtigkeit. In W. Kersting (Hrsg.). Freiheit und Gerechtigkeit - die moralischen Grundlagen der Sozialen Marktwirtschaft (pp. 45-62). Frankfurt am Main, Bundesrepublik Deutschland: Peter Lang.

Loungani, P., \& Sheets, N. (1997). Central bank independence, inflation, and growth in transition economies. Journal of Money, Credit, and Banking, 29(3), 381-399.

Lutz, F. A. (1953). Einwände gegen die Wettbewerbsordnung - ein Gespräch mit studenten. ORDO - Jahrbuch für die Ordnung von Wirtschaft und Gesellschaft, Bd. 5, 245-266.

Lutz, F. A. (1962). Geld und Währung - gesammelte Abhandlungen. Tübingen, Bundesrepublik Deutschland: J. C. B. Mohr.

Lutz, F. A. (1971). Politische Überzeugungen und Nationalökonomische Theorie - Züricher Vorträge. Tübingen, Bundesrepublik Deutschland: J. C. B. Mohr.

Müller-Armack, A. (1962). Das gesellschaftspolitische Leitbild der Sozialen Marktwirtschaft. In E. Tuchtfeldt, \& E. Dürr (Hrsg.). Genealogie der Sozialen Marktwirtschaft: Frühschriften und weiterführende Konzepte, 1981, (pp. 146-162). Stuttgart, Bundesrepublik Deutschland: Verlag Paul Haupt.

Müller-Armack, A., \& Erhard, L. (1972). Soziale Marktwirtschaft, Ordnung der Zukunft: Manifest '72. Frankfurt am Main, Bundesrepublik Deutschland: Ullstein. 
Nawroth, E. E. (1961). Die sozial - Und wirtschaftsphilosophie des neoliberalismus. Heidelberg, Bundesrepublik Deutschland: F. H. Kerle Verlag.

Röpke, W. (1957). Eigentum als Säule einer freien Gesellschaft. Schweizer Monatshefte, 37(6), 441-447.

Röpke, W. (1961). Marktwirtschaft und ordnung des wettbewerbes. In J. Höffner, A. Verdross, \& F. Vito (Hrsg.). Naturordnung in Gesellschaft, Staat, Wirtschaft (pp. 624-631). Innsbruck, Republik Österreich: Tyrolia-Verlag.

Rüstow, A. (1960). Das christliche gewissen und die soziale marktwirtschaft des neoliberalismus. Junge Wirtschaft: Zeitschrift für fortschrittlichen Unternehmertum, 2, 46-52.

Simonazzi, A., Ginzburg, A., \& Nocella, G. (2013). Economic relations between Germany and Southern Europe. Cambridge Journal of Economics, 37(3), 653-675. doi. org/10.1093/cje/bet010

Stegmann, F. -J. (1999). Social market economy and morality Contradictory or complementary. Johannesburg, Republic of South Afrika: Konrad-Adenauer-Stiftung.

Storm, S., \& Naastepad, C. W. M. (2015). Crisis and recovery in the German economy: The real lessons. Structural Change and Economic Dynamics, 32(C), 11-24. doi.org/10.2139/ ssrn. 2638053
Symanski, T. (1999). Die Mittelstandsorientierung in der Konzeption der Sozialen Marktwirtschaft - mit einer kritischen Betrachtung der deutschen Wirtschafts - und Gesellschaftslage. Marburg, Bundesrepublik Deutschland: Tectum Verlag.

Vanberg, V. (1988). Ordnungs theorie as constitutional economics - The German conception of a Social Market Economy. ORDO: Jahrbuch für die Ordnung von Wirtschaft und Gesellschaft, 39, 17-31.

Vanberg, V. (2002). Soziale Sicherheit, Müller-Armacks "Soziale Irenik" und die ordoliberale Perspektive. In R. H. Hasse, \& F. Quaas (Hrsg.). Wirtschaftsordnung und Gesellschaftskonzept: Zur Integrationskraft der Sozialen Marktwirtschaft (pp. 227-259). Bern, Switzerland: Verlag Paul Haupt.

Wrobel, R. M. (2012). The social market economy as a model for sustainable growth in developing and emerging countries. Economic and Environmental Studies, 12(1), 47-63.

Wrobel, R. M. (2014). Cambodia's transition to sustainable development: Preconditions, recommendations, obstacles. Central and Eastern European Journal of Management and Economics (CEEJME), 2(2), 71-92.

Zweynert, J. (2015). The concept of Ordnungspolitik through the lens of the theory of limited and open access orders. Constitutional Political Economy, 26(1), 4-18. doi:10.1007/ s10602-014-9173-Z

Primljeno 28. juna 2018, nakon revizije, prihvaćeno za publikovanje 22. avgusta 2018. Elektronska verzija objavljena 27. avgusta 2018.

Vladan Ivanović je docent na Ekonomskom fakultetu Univerziteta u Kragujevcu. Doktorirao je na Ekonomskom fakultetu Univerziteta u Kragujevcu, a trenutno je doktorand na Univerzitetu Hohenhajm u Štutgartu, Savezna Republika Nemačka. Ključne oblasti njegovog interesovanja su ekonomska politika, javne politike i institucionalna ekonomija. 


\title{
FROM ORDER TO PROSPERITY: THE IMPORTANCE OF COMPETITION IN THE SOCIAL MARKET ECONOMY MODEL
}

\author{
Vladan Ivanovic* \\ Faculty of Economics, University of Kragujevac, Kragujevac, The Republic of Serbia
}

\begin{abstract}
Searching for an institutional structure which enables economic success is in the midst of the practical efforts of governments all around the world, as well as the academic studies endeavoring to understand the sources of success in the most prosperous national economies. The supremacy of the German economy in the European Union, as well as worldwide - from the level of the GDP per capita to high productivity, innovativeness and export performances - is the basic motivation this study rests on. Due to the fact that, unlike a failure, an economic success is always achieved in the long run, this study is aimed at revealing the (historical) institutional roots that have paved the way for the economic success of contemporary Germany. In that context, the model of the Social market economy, i.e. the competitive order (Wettbewerbsordnung), its meaning and importance in solving the allocative equation and reaching the high levels of economic efficiency are the subject matter of analysis in this paper. The key results refer to the identification of the diverse economic and social benefits that a competitive order brings into being, as well as the determination of and pointing to the essential institutional preconditions which such an order is feasible in.
\end{abstract}

Keywords: Social market economy, German model, competition, economic efficiency, institutions

JEL Classification: B25, B52, P10 